Article

\title{
Do Energy Resource Curse and Heterogeneous Curse Exist in Provinces? Evidence from China
}

\author{
Hui Hu ${ }^{1,2, *}$, Weijun Ran ${ }^{2}$, Yuchen Wei ${ }^{2}$ and Xiang $\mathrm{Li}^{3, *}$ \\ 1 Economic Development Research Centre, Wuhan University, Wuhan 430072, China \\ 2 School of Economics and Management, Wuhan University, Wuhan 430072, China; \\ weijun.ran@whu.edu.cn (W.R.); weiyuchen1999@whu.edu.cn (Y.W.) \\ 3 Carroll School of Management, Boston College, Chestnut Hill, MA 02467, USA \\ * Correspondence: hui.hu@whu.edu.cn (H.H.); licsr@bc.edu (X.L.)
}

Received: 15 June 2020; Accepted: 19 August 2020; Published: 25 August 2020

check for updates

\begin{abstract}
This study aims to find the relationship between energy resource dependence and economic growth in consideration of interprovincial heterogeneity. This paper first uses panel data from 14 provinces with rich energy resources in China between 2001 and 2016 as a whole to test the energy resource curse hypothesis. It finds that there is no obvious resource curse from a general perspective. It further makes time prediction and transmission channel analysis based on regressions of each province and classifies them into four groups according to the different degrees of the resource curse. It shows the different roles of resource dependencies in different groups. Twelve provinces are subject to different degrees of the resource curse, among which, six provinces would eventually experience negative economic growth if they increase the degree of resource dependence. Next, this study discusses the mechanism of one particular group, "invisible energy resource curse", which is when energy resources directly promote but indirectly hinder economic growth. Finally, based on the results, the present study offers policy suggestions according to provinces' heterogeneous curse levels.
\end{abstract}

Keywords: energy resource curse; energy resource-abundant provinces; economic growth; transmission channels; classification analysis; time prediction

\section{Introduction}

Since the abundance of natural resources can slow economic growth, resource-poor economies often vastly outperform resource-rich economies in economic growth [1,2]. Known as the resource curse theory, many studies have found empirical evidence to support it in recent years [3-6]. Economies with rich natural resources tend to fall into the comparative advantage trap. If the developing countries with rich resources focus on the exploitation of natural resources, the polarization of wealth between owners of natural resources and the people lacking natural resources could increase. This would generate a group of vested interest-takers. These interest-takers would, in turn, hinder technological innovation and institutional reform in a variety of ways [7-9].

As an important part of natural resources, energy resource exploitation usually cannot optimize the industrial structure of the whole region [10-12]. In other words, energy resource exploitation would slow down their economic growth or even cause a stagnant economy in the long run. Researchers have confirmed this conjecture in several studies on energy resource-dependent economies [13-17].

However, some studies also point out that some countries with rich energy resources are likely to experience resource blessings. With the development of energy resource exploration and export, some countries with rich resources will change their mode of economic development, improve the investment in education, and accelerate human capital accumulation [1]. Some countries that are plentiful in energy resources, like Malaysia and Indonesia, succeed in avoiding the resource curse [18]. 
Most early literature focuses on identifying whether the energy resource curse exists in different countries [19-21]. They discover that compared with energy resource blessing, the resource curse is relatively more prevalent. Havranek et al. [22] note that approximately $40 \%$ of empirical studies have found energy resource curse, while just $20 \%$ have found energy resource blessing. However, most of these studies focus on the national level rather than the provincial level. The researches based on the national level are too macroscopic to ensure the correctness of the research results. Fleming-Muñoz et al. [23] suggest that the research results from a regional perspective could significantly differ from those from the national perspective. By econometrically modeling economic growth across nonmetropolitan sub-state regions of Australia, they find that in most cases, energy resources have been a blessing for local economies, although negative effects have also been experienced in parts of the country.

Because of this, many scholars begin to consider this problem from a more micro angle. Most Chinese scholars believe that the phenomenon of the energy resource curse does exist at the provincial level. They carry out detailed studies on possible transmission channels of the energy resource curse. However, none of them have systematically studied the similarities and differences of provinces that are endowed with rich energy resources in China. This study chooses provinces rich in energy resources in China as a sample to study the resource curse. It tests the hypothesis of the energy resource curse in 14 energy resource-rich provinces. Different from prior studies, this paper studies their resource curse individually on the premise of the overall results. Using time prediction and channel analysis, it could confirm the advent of "energy resource curse" at the provincial level. Furthermore, it classifies 14 provinces into 4 categories and discusses each category.

Since the energy resource curse exists in energy resource-rich regions, this paper focuses on 14 provinces that are rich in energy resources in China to test the energy resource curse hypothesis. The main contributions of this paper are as follows. First, the existence of the energy resource curse is not detected in these 14 provinces while regarding them as a whole. However, it is observed while investigating each province respectively, which indicates that the heterogeneous curse exists. Second, this study recognizes the internal differentiation of the energy resource curse. By introducing the time prediction model and the Sachs-Warner model (S-W model), it can classify 14 provinces into specific groups based on the degree of the energy resource curse. This study shows that causes and situations vary with groups. Based on this, we provide customized policy suggestions to different groups. Third, this paper introduces the concept of the "invisible energy resource curse", where energy resources have a directly positive but indirectly negative effect on economic growth. We investigate the mechanism of the "invisible energy resource curse" and give policy advice.

The remainder of this study is organized as follows: Section 2 reviews previous literature. Section 3 presents the methodology, sample selection, as well as data information. Section 4 presents the empirical results. Section 5 deals with conclusions and policy implications.

\section{Literature Review}

Some empirical studies confirm the existence of the energy resource curse, namely on the negative correlation between energy endowments and economic growth. For example, Japan, South Korea, Singapore, and Hong Kong, with relatively scarce energy resources, experienced fast economic growth $[18,24,25]$. In stark contrast to this, countries endowed with rich energy resources, such as Latin America [26], Kazakhstan [27], Nigeria [28], and Venezuela [29], are experiencing economic stagnation. Auty [30], the founder of the resource curse theory, admits that energy resource abundance per se does not necessarily culminate in the energy resource curse. Whether energy resources are a "curse" or a "blessing" to the economic growth should be analyzed on a case-by-case basis.

In China, several scholars investigate the energy resource curse from different angles. From the regional perspective, $\mathrm{Xu}$ et al. [31] demonstrate that a generalized "energy resource curse" emerges owing to the excessive exploitation of energy resources and its related environmental pollution. It exists in northeast and northwest China. Shao and Qi [32] suggest that the "energy resource curse" existed 
in western China before the implementation of the national western development strategy, but the curse's effect is not obvious. However, after the western development, energy development began to exert a significant negative impact on innovation and human capital investment, which aggravates the "energy resource curse".

From the provincial perspective, $\mathrm{Xu}$ and $\mathrm{Hu}$ [33] find that based on the relationship between energy resources and economic growth, Dutch disease would pose a negative impact on Inner Mongolia in the long run. However, the effects of the energy resource curse have been mitigated since the Chinese government began to promote the development of the western regions and implement environmental regulations. From the civic perspective, Sun and Ye [34] study the relationship between energy resource dependence, geographical location, and economic growth in urban areas of China. They find that energy resource endowments seem to be negatively correlated with economic growth. Shao et al. [35] use the data of 220 cities in China between 1998 and 2010 to measure the efficiency of economic growth. Their research shows that there is a significant parabolic correlation between energy-dependent industries and the average growth rate of Gross Domestic Product (GDP) per capita.

From a more micro perspective, Ding et al. [36] also find the existence of an energy resource curse at the level of villages in China. Energy resources could reduce the per capita income of residents by crowding out local education investment, technological innovation, and reducing the quality of institutions. Nevertheless, some studies show different results. Fang et al. [37] use cross-section data concerning 95 cities in China and find that the resource curse hypothesis cannot hold water. This is because a significantly negative correlation between resource abundance and economic growth cannot be observed. Deng et al. [38] indicate that the problem of the resource curse is not so serious in China. Sun and Si [39] use Chinese cross-sectional data from 1996 to 2008 and find that neither resource abundance nor resource dependency display a significant relationship with regional economic growth. Cao et al. [40] conclude that the "energy resource curse" is not significant at the municipal level in China. Furthermore, Wang et al. [41] and Chen and Kung [42] find that the varied rates of cities' economic growth are mainly due to cities' divergent conditions. They include geographical, natural, political, and demographic conditions.

Studies on the transmission channels of the energy resource curse in China appeared in the past decade. Guo et al. [43] find that the total effect of energy resource dependency on economic output would increase to 10 times the direct effect, if the indirect impacts of the transmission channels are included. Through these channels, energy resources would decrease economic output. Li [44] points out that the abundance of energy resources does not directly generate a negative impact on economic growth at the provincial level. However, it indirectly hinders economic growth by reducing foreign direct investment, education, and innovation, among which, foreign direct investment is the most important transmission channel. Wang [45] selects 34 energy resource-based cities in China and devises a conceptual model on transmission mechanisms, which consist of direct effect, crowding-out effect, and institutional effect. Yang and Shao [46] find that human capital and energy resources play a crucial role in the sustainable growth of energy-oriented regions. They suggest that the brain drain could discourage social planners from accelerating human capital accumulation, thereby resulting in increased risks of the energy resource curse in energy-oriented regions. Shao and Qi [32] suggest that the exploitation of energy resources impedes economic growth through several transmission channels. It will likely hinder the technical innovation and the accumulation of human capital, which causes rent-seeking activities and widespread corruption in associated industries. Zuo and Schieffer [47] further describe the crowding-out effect through aspects of education and research and development, as opposed to the institutional explanation. 


\section{Data and Method}

\subsection{Model Setting}

The economic growth theory claims that economic growth, especially in the long run, is largely based on the increase of inputs such as capital, labor, and land [48]. The increase in GDP per capita is frequently introduced to measure economic growth, and the absolute convergence hypothesis, namely that the GDP per capita in different regions within a country usually converges to a steady-state, has been frequently applied in prior studies [49-52]. The hypothesis also suggests that, in a country, a region's initial GDP per capita in a given period negatively influences its growth rate (Figure 1). Some early studies incorporate the initial GDP level into their economic growth regressions [19-21]. In this study, the previous year's GDP is used in the regression to check the absolute convergence hypothesis. We find that between the adjacent two years, the lower the previous year's state GDP, the higher the current year's economic growth rate.

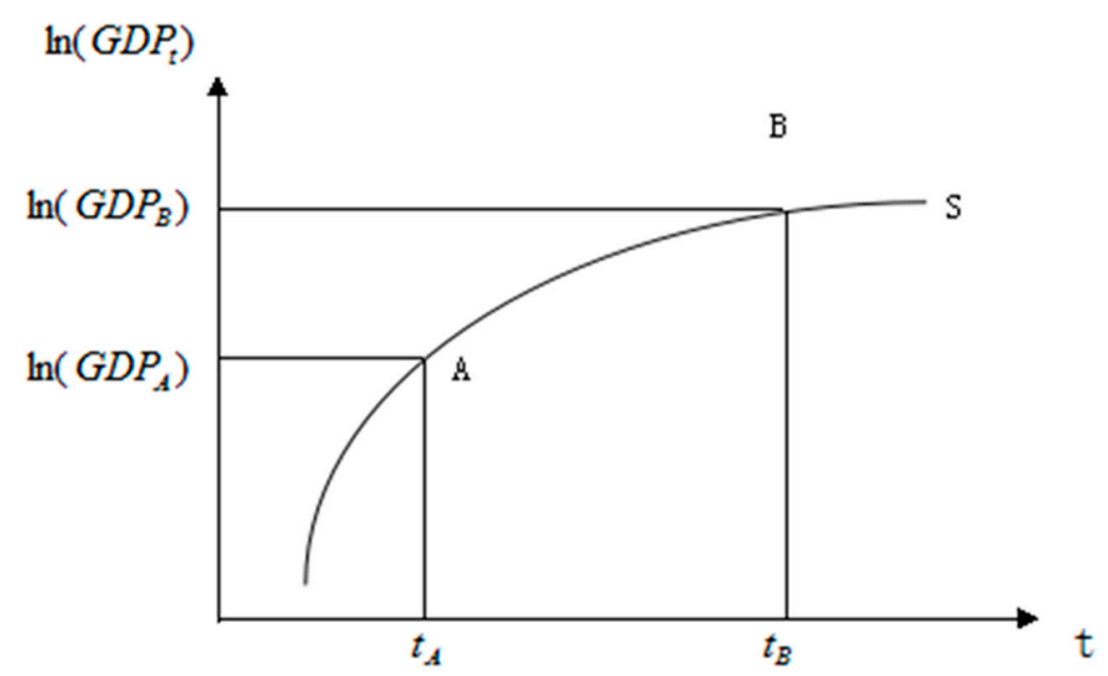

Figure 1. Absolute convergence. Note: $A$ and $B$ denote two random times, respectively. The gross provincial product growth rate on time $\mathrm{A}\left(t_{A}\right)$ is higher than time $\mathrm{B}\left(t_{B}\right)$, though $t_{B}$ is linked to a higher gross provincial product. The growth rate decreases as the gross provincial product increases, and $S$ represents the final steady-state.

This paper uses the S-W model [19] for reference and sets the regression model as follows:

$$
g_{i t}=\beta_{i 0}+\beta_{i 1} \ln \left(g d p_{i, t-1}\right)+\beta_{i 2} R D_{i t}+\beta_{i 3} Z_{i t}+\varepsilon_{i t}
$$

In Equation (1), $g_{i t}$ denotes the per capita GDP growth rate of each province, $\ln \left(g d p_{t-1}\right)$ represents the per capita GDP of each province last year, $R D_{i t}$ represents the energy resource dependency of the province, $Z_{i t}$ denotes five transmission channels: investment (INV), foreign direct investment (FDI), level of nationalization (NAT), manufacturing output level (MAN), and level of education (EDU), and $\varepsilon_{i t}$ represents the random disturbance term. In this study, the current year is coded as $t$ and the previous year is coded as $t-1$. The footer $i$ refers to the province.

$g_{i t}$, an indicator of economic growth rate, measures the growth rate of gross provincial product per capita of provinces:

$$
g_{i t}=\ln \left(\frac{g d p_{i t}}{g d p_{i, t-1}}\right)
$$

The logarithm of $g d p_{i t}$ divided by the $g d p_{i, t-1}$ enables us to examine the absolute convergence hypothesis. We expect the coefficient $\beta_{1}$ to be negative because the previous year's gross provincial product per capita can negatively influence the economic growth in the current year [32]. 
$R D_{i t}$ represents the energy resource dependency. Papyrakis and Gerlagh [21] use the proportion of energy products in GDP to quantify $R D_{i t}$, while Sachs and Warner [20] use the percentage of energy capital in total capital. Sun and Ye [34] use the percentage of energy exploitation employment in gross employment. Zuo and Schieffer [47] employ three different proxies for $R D_{i t}$, including provincial annual energy production per capita, provincial annual energy production, and the ratio of the regional energy production over GDP.

This study uses the proportion of fixed-asset investment in energy resource exploitation to total fixed-asset investment to quantify the extent of energy resource dependency. According to the statistical standards in China, energy exploitation input levels depend unconditionally on the availability of energy resources. In addition, the output value of the primary production sector is affected by the level of regional economic development, resulting in endogeneity, and the use of an input level indicator can avoid endogeneity to a large extent [53-55]. Therefore, it is a more appropriate proxy. We include coal, crude oil, gas, and other fossil fuels as an approximation of all the energy resource industries.

$\beta_{i 2}$ measures the degree of contribution of the energy resources' dependency on economic growth. We expect $\beta_{i 2}$ to be negative, which means energy resource dependence impedes economic growth directly. $Z_{i t}$ refers collectively to the following variables: the crowding-out-effect variables and the institutional variables.

Manufacturing is the growth engine of China's economy, and it has been the main powerhouse promoting economic growth. Thus, the effects of the exploitation of energy resources on manufacturing need to be scrutinized [56]. The most well-known effect is 'the Dutch disease', which mainly refers to the crowding-out effects on manufacturing caused by energy resource exploitation. Considering this potential influence, our analysis includes MAN, which is measured by the proportion of the sales value of the manufacturing industry above the scale to the total sales value of the industry. Since the development in manufacturing usually boosts economic growth, we expect the coefficient of MAN to be positive.

In China, the foreign direct investment and level of nationalization also play important roles in economic growth $[34,57]$. INV, as well as EDU, also significantly contribute to the economic growth according to prior studies, such as Papyrakis and Gerlagh's study [21]. Therefore, variables that involve the crowding-out effects include the INV, FDI, and EDU. INV and FDI are measured respectively in terms of the total investment in fixed assets and foreign direct investment. EDU indicates the proportion of the population with a college degree and higher in the total population aged 6 and above. They are included in this model and their coefficients are expected to be positive. This is because China has set a higher threshold for the entry of foreign capital. Moreover, provinces with a high degree of resource dependence are located in remote areas and only have a weak ability to attract foreign investment [58].

As for INV, dependence on energy resources reduces the need for savings and investments. It is because energy resources provide a continuous stream of future wealth that is less dependent on the transfer of man-made capital to future periods [59]. Furthermore, the prices of primary products are often more volatile than those of manufactured commodities. This volatility, rather than the level of energy resources' prices, poses a negative effect on economic growth [60-62]. Therefore, a region that is heavily dependent on energy resources would suffer more frequent economic fluctuations, resulting in unstable investment markets [63]. For EDU, in the regions that are endowed with abundant energy resources, the continuous economic growth brought by energy resources breeds laziness. Since high-quality talents are not demanded by the primary sector, people find it unnecessary to receive high education. Investment in human capital would slow down or even stop [19].

It is a significant issue to measure the institutional variables as there is no measurement standard in the literature. This study uses NAT measured by the proportion of the sales value of state-owned and state-holding industries to that of the society. In regions depending on energy resources, some local governments tend to lower the investment threshold and blindly introduce energy-intensive enterprises to boost the local economy. Some state-owned enterprises with backward technologies 
and administration still having the privilege of exploiting resources lead to low energy efficiency and serious environmental pollution [64]. Consequently, it hinders the sustainable development and economic growth of energy resource-rich regions [11,34].

To better reflect the relationship between energy resource dependence and economic growth, this paper eliminates the effects of inflation by dividing several indicators by Consumer Price Index (CPI). Indicators processed as above include MAN, INV, FDI, NAT, and GDP. As mentioned above, this paper will focus on the interaction between the five channels and energy resource dependency.

\subsection{Sample Selection}

Sachs and Warner [20] use the ratio of primary exports to GDP to represent energy resource endowments. Stijns [65] argues that if a country's structure of export is resource-intensive, it is not necessary to indicate that it is a country with rich energy resources. Therefore, it is not accurate to use an index like that. Indicators like resource production or resource reserve should be used instead. Gylfason [66] adopts primary sector employment to total employment proportion as a representation of the resource endowments. Papyrakis and Gerlagh [21] use primary sector output as a share of GDP to replace the primary product exports to GDP ratio to study the correlation between energy resource abundance and economic growth. This paper uses the proportion of energy exploitation sector employment in total employment to represent the richness of energy resource endowments, referring to Gylfason's study [66]. We collected the data from 2000 to 2010, and the indicator serves as a criterion to screen out provinces with rich energy resources in China.

Due to the availability of data, Hong Kong, Macao, and Taiwan are excluded in the data, namely the region shown as not applicable (NA) in Figure 2. This paper divides the richness of energy resources into three equal parts. The evolution of rank 1 to rank 3 indicates the increase of energy resource richness. Therefore, we screened out 14 provinces with level 3 in 2000 and 2010 as our objects to further explore the relationship between their energy resource richness and economic growth. These 14 provinces include Guizhou, Hebei, Heilongjiang, Inner Mongolia, Jiangxi, Jilin, Liaoning, Ningxia, Qinghai, Shaanxi, Shandong, and Shanxi.

\section{0 , China}

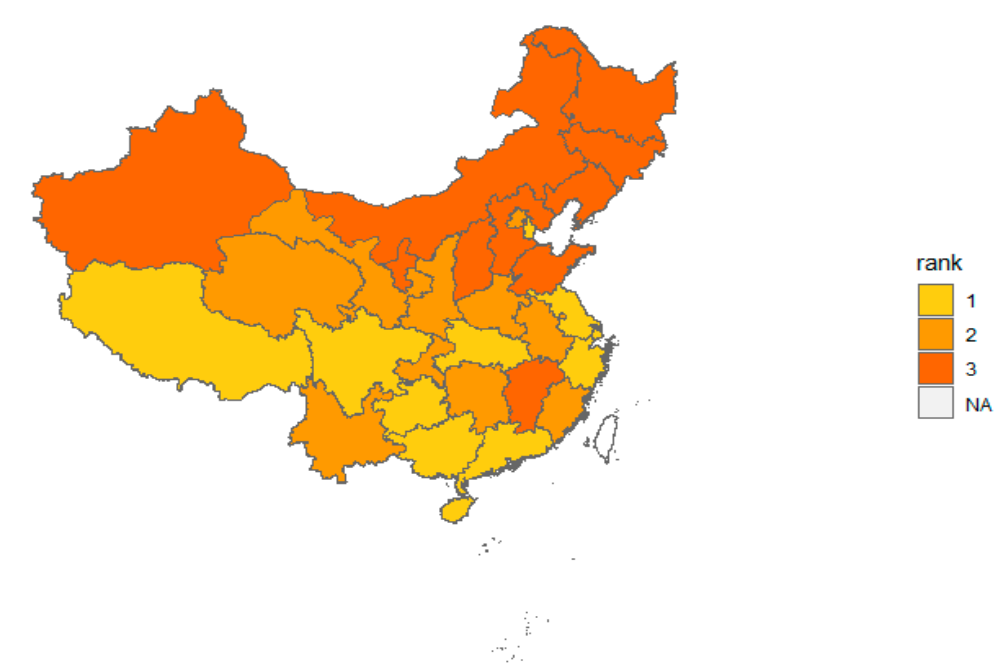

(a) 2000

Figure 2. Cont. 

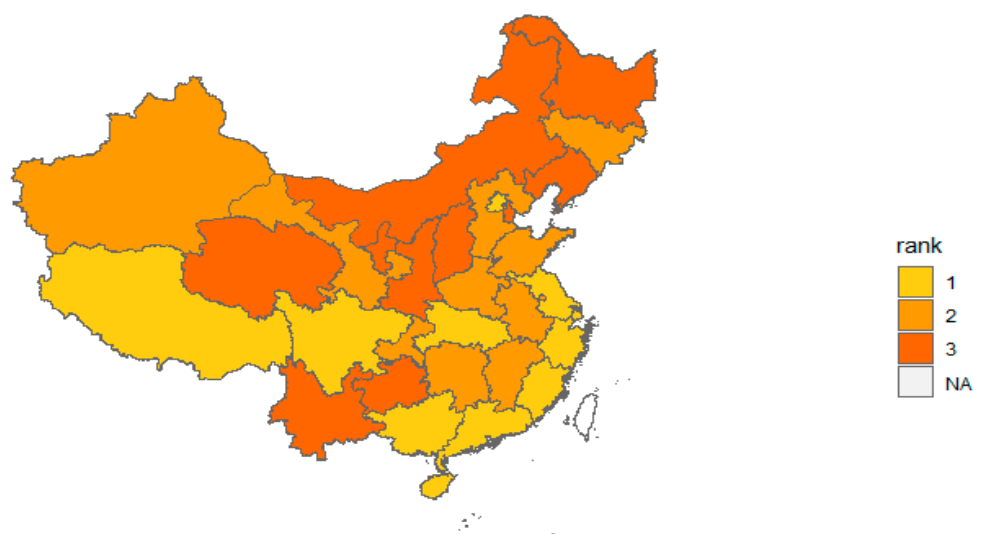

(b) 2010

Figure 2. Distribution of the proportion of employment in the energy resource exploitation industry to total number of employed people in (a) 2000 and (b) 2010, in China.

\subsection{Data and Descriptive Statistics}

This study uses data of 14 provinces from 2001 to 2016. Data are from the yearbooks of each province: China Industrial Economic Statistical Yearbook, China Statistical Yearbook of Investment in Fixed Assets, China Statistical Yearbook, China Foreign Economic Statistical Yearbook, China Population and Employment Statistics Yearbook, China Statistical Yearbook for Regional Economy, and the Compilation of Statistical Data for the Past 60 Years in China. Table 1 lists all the variables included in the model.

Table 1. List of variables in the regressions.

\begin{tabular}{|c|c|c|c|c|}
\hline Category & Variable & $\begin{array}{l}\text { Abbreviation } \\
\text { or Acronym }\end{array}$ & Definition & $\begin{array}{l}\text { Previous Studies } \\
\text { Using the Variable }\end{array}$ \\
\hline $\begin{array}{l}\text { Dependent } \\
\text { variable }\end{array}$ & $\begin{array}{l}\text { Economic growth } \\
\text { rate }\end{array}$ & $g_{i t}$ & $g_{i t}=\ln \left(\frac{g d p_{i, t}}{g d p_{i, t-1}}\right)$ & {$[21]$} \\
\hline $\begin{array}{l}\text { Independent } \\
\text { variable }\end{array}$ & $\begin{array}{l}\text { Log of gross } \\
\text { provincial product } \\
\text { per capita in last } \\
\text { term }\end{array}$ & $\ln \left(g d p_{i, t-1}\right)$ & $\begin{array}{l}\text { The logarithm of the real per } \\
\text { capita gross domestic product } \\
\text { of province } i \text { in last year }\end{array}$ & {$[21]$} \\
\hline $\begin{array}{l}\text { Independent } \\
\text { variable }\end{array}$ & $\begin{array}{c}\text { Energy resource } \\
\text { dependency }\end{array}$ & $R D_{i t}$ & $\begin{array}{l}\text { The proportion of investment } \\
\text { in energy resource } \\
\text { exploitation industry in total } \\
\text { fixed assets investment }\end{array}$ & {$[20,34]$} \\
\hline $\begin{array}{l}\text { Independent } \\
\text { variable }\end{array}$ & $\begin{array}{l}\text { Fixed-asset } \\
\text { investment }\end{array}$ & $I N V_{i t}$ & Total fixed assets investment & {$[21]$} \\
\hline $\begin{array}{l}\text { Independent } \\
\text { variable }\end{array}$ & $\begin{array}{l}\text { Foreign direct } \\
\text { investment }\end{array}$ & $F D I_{i t}$ & Foreign direct investment & [34] \\
\hline $\begin{array}{l}\text { Independent } \\
\text { variable }\end{array}$ & Educational level & $E D U_{i t}$ & $\begin{array}{l}\text { The proportion of the } \\
\text { population aged } 6 \text { and above } \\
\text { who are junior college } \\
\text { graduates or above accounts } \\
\text { for the total population aged } 6 \\
\text { and above }\end{array}$ & [21] \\
\hline
\end{tabular}


Table 1. Cont.

\begin{tabular}{ccccc}
\hline Category & Variable & $\begin{array}{c}\text { Abbreviation } \\
\text { or Acronym }\end{array}$ & Definition & $\begin{array}{c}\text { Previous Studies } \\
\text { Using the Variable }\end{array}$ \\
\hline $\begin{array}{c}\text { Independent } \\
\text { variable }\end{array}$ & $\begin{array}{c}\text { Manufacturing } \\
\text { output level }\end{array}$ & MAN $N_{i t}$ & $\begin{array}{c}\text { The proportion of the sales } \\
\text { output value of the } \\
\text { manufacturing industry above } \\
\text { the scale in the total sales } \\
\text { output value of the industry }\end{array}$ \\
\hline $\begin{array}{c}\text { Independent } \\
\text { variable }\end{array}$ & $\begin{array}{c}\text { Level of } \\
\text { nationalization }\end{array}$ & $N A T_{i t}$ & $\begin{array}{c}\text { The proportion of the sales } \\
\text { output value of state-holding } \\
\text { industries above the scale in } \\
\text { the total sales output value of } \\
\text { the industry }\end{array}$ & {$[34]$} \\
\hline
\end{tabular}

\section{Empirical Analyses and Results}

\subsection{Whether the Energy Resource Curse Exists}

This paper further discusses the existence of the resource curse in 14 provinces endowed with rich energy resources.

\subsubsection{General panel—Data Regressions}

To find an appropriate regression method, it is necessary to identify characteristics of cross-sectional independence, autocorrelation of residuals, and heteroscedasticity. This paper applied relevant tests and Table 2 shows the results.

Table 2. Results of relevant tests.

\begin{tabular}{cccc}
\hline Purpose & Method & Statistics & Result \\
\hline $\begin{array}{c}\text { Cross-sectional } \\
\text { independence }\end{array}$ & Pesaran's test & $\begin{array}{c}\text { Pesaran's statistics } \\
(p=0.000)\end{array}$ & $\begin{array}{c}\text { Cross-sectionally } \\
\text { dependent }\end{array}$ \\
\hline Autocorrelation & Wooldridge test & $\begin{array}{c}\mathrm{F}=22.478 \\
(p=0.0004)\end{array}$ & Autocorrelation \\
\hline Heteroscedasticity & Wald test & $\begin{array}{c}\chi^{2}=191.76 \\
(p=0.000)\end{array}$ & Heteroscedasticity \\
\hline $\begin{array}{c}\text { Fixed-effect or } \\
\text { random-effect }\end{array}$ & $\begin{array}{c}\text { Hausman test with } \\
\text { auxiliary regression }\end{array}$ & $\begin{array}{c}\mathrm{F}=7.7 \times 10^{14} \\
(p=0.000)\end{array}$ & Fixed effect \\
\hline Endogeneity & Hausman test & $\begin{array}{c}\chi^{2}=5.61 \\
(p=0.6914)\end{array}$ & Exogenous \\
\hline
\end{tabular}

After applying the tests in Table 2 above, we find that the fixed-effect model should be used. Since data present characteristics of contemporaneous correlation, autocorrelation of residuals, and heteroscedasticity, this study chooses fixed effect regression models with Driscoll and Kraay standard errors [68]. In the derivation of Driscoll and Kraay standard errors, the disturbance $\varepsilon_{i t}$ is allowed to be autocorrelated, heteroskedastic, and cross-sectionally dependent, so the estimation is well calibrated when spatial dependence exists [69]. We also applied the Hausman test to endogeneity problems by using the value of energy reserves as an instrumental variable. It supports the null hypothesis that the model is exogenous, and shows that the proxy variable $R D_{i t}$ can avoid endogeneity problems. The above model was applied to the estimation of Equation (1) for 14 provinces. Table 3 shows the result. 
Table 3. Regressions for Equation (1).

\begin{tabular}{ccccccc}
\hline & $\mathbf{( 1 )}$ & $\mathbf{( 2 )}$ & $\mathbf{( 3 )}$ & $\mathbf{( 4 )}$ & $\mathbf{( 5 )}$ & $\mathbf{( 6 )}$ \\
\hline Lngdp & $\mathbf{g}$ & $\mathbf{G}$ & $\mathbf{g}$ & $\mathbf{g}$ & $\mathbf{g}$ & $\mathbf{g}$ \\
\hline \multirow{2}{*}{ RD } & $-0.0421^{* * *}$ & $-0.0544^{* * *}$ & $-0.0392^{* * *}$ & $-0.0392^{* * *}$ & $-0.0467^{* * *}$ & $-0.0635^{* * *}$ \\
& $(0.011)$ & $(0.009)$ & $(0.012)$ & $(0.012)$ & $(0.012)$ & $(0.020)$ \\
MAN & $0.698^{* * *}$ & $0.466^{*}$ & $0.352^{* *}$ & $0.364^{* *}$ & $0.340^{* *}$ & $0.362^{* *}$ \\
& $(0.229)$ & $(0.256)$ & $(0.144)$ & $(0.137)$ & $(0.133)$ & $(0.143)$ \\
EDU & & $-0.236^{* * *}$ & $-0.143^{* *}$ & $-0.136^{* *}$ & $-0.0985^{*}$ & -0.0892 \\
& & $(0.055)$ & $(0.050)$ & $(0.053)$ & $(0.048)$ & $(0.056)$ \\
NAT & & $-0.736^{* * *}$ & $-0.653^{* *}$ & $-0.361^{*}$ & $-0.448^{*}$ \\
& & $(0.178)$ & $(0.232)$ & $(0.195)$ & $(0.234)$ \\
FDI & & & 0.0273 & $0.0697^{*}$ & $0.100^{* * *}$ \\
& & & $(0.044)$ & $(0.038)$ & $(0.033)$ \\
INV & & & & $0.0210^{* * *}$ & $0.0208^{* * *}$ \\
& & & & $(0.006)$ & $(0.006)$ \\
CONS & $0.0953^{*}$ & $0.320 * * *$ & $0.268^{* * *}$ & $0.243 * * *$ & $0.176^{* *}$ & $0.198^{* *}$ \\
& $(0.045)$ & $(0.045)$ & $(0.045)$ & $(0.057)$ & $(0.063)$ & $(0.072)$ \\
N & 224 & 224 & 224 & 224 & 224 & 224 \\
R2 & 0.1257 & 0.1495 & 0.2144 & 0.2161 & 0.2693 & 0.2774 \\
\hline
\end{tabular}

Standard errors in parentheses. ${ }^{* * *}, * *$, and $*$ indicate a $1 \%, 5 \%$, and $10 \%$ level of significance, respectively. CONS refers to constant; $N$ refers to number; $R 2$ refer to $R$ square.

In Table $3, \ln \left(g d p_{i, t-1}\right)$ has a negative and significant coefficient and it verifies the robustness of the model. The coefficient of $R D_{i t}$ is significantly positive, which means that the energy resources of the 14 provinces as a whole seem to have a positive impact on economic growth. This conflicts with the expectation. Additionally, Figure 3 suggests that most of the 14 provinces present a downward trend in their dependence on energy resources. If "energy resource blessing" is a common phenomenon, inevitably, there would be some provinces that succeed in achieving faster economic growth by increasing the degree of energy resource dependence [70]. Thus, the significantly positive coefficient of $R D_{i t}$ could not directly denote the existence of "resources blessing" in each province. In other words, the differences in energy resource dependence among the provinces conceal the actual relationship between energy resources dependence and economic growth. It is necessary to adopt another method which can accurately measure the coefficient of $R D_{i t}$ for each province. 


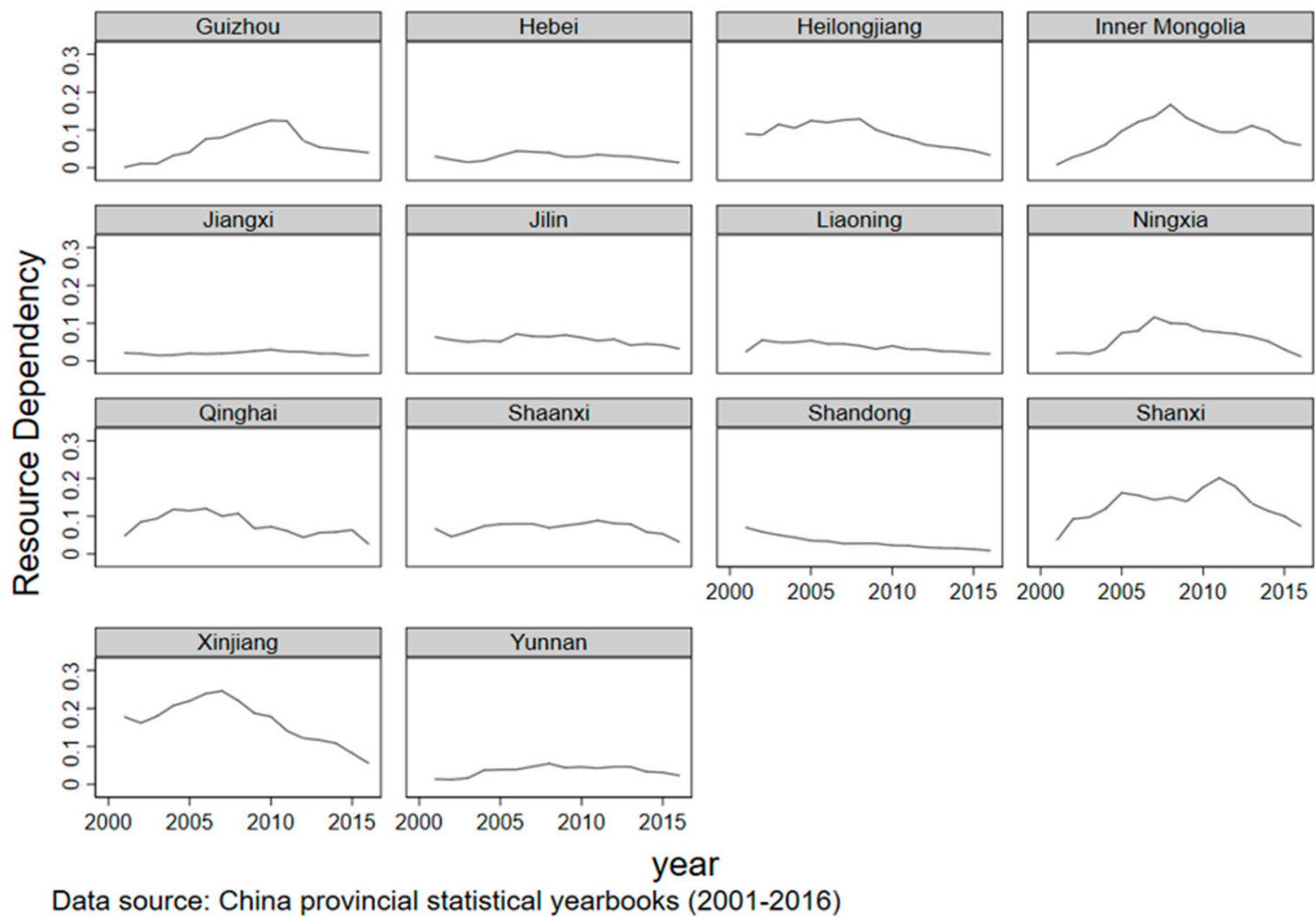

Figure 3. Energy resource dependence of each province, 2001-2016.

\subsubsection{Respective Regressions for Provinces}

This study conducts regressions for each province and introduces the prediction model. It further analyses the transmission channels in each province and uses Equation (1) for province estimation. Equation (1) can be estimated equation-by-equation for each province using ordinary least squares (OLS). Considering the correlation of stochastic disturbances of provinces, this study uses the panel data seemingly unrelated estimation (SUR) method. The SUR method takes consideration of heteroskedasticity and contemporaneous correlation in the errors across equations [71]. Compared with the OLS method, this gains efficiency improvement under the hypothesis that stochastic disturbances are highly correlated across equations and independent variables are not [72]. Table 4 shows the result.

The results of SUR regressions show that different channel variables have different impacts on the economic growth of different provinces. MAN's coefficients are significant in 10 provinces, among which, 7 are significantly negative, indicating that the manufacturing industry has a significant impact on most provinces. EDU's coefficients of 4 provinces are significantly positive. However, they are not significant or are even significantly negative in other provinces. NAT's coefficients are significantly positive in 8 provinces. FDI's coefficients are significantly positive in 3 provinces and negative in another 3 provinces. INV's coefficients are significantly positive in 8 provinces and negative in 3 provinces. It indicates that investment has different effects on the economy in different provinces. 
Table 4. Seemingly unrelated estimation (SUR) regressions for each province.

\begin{tabular}{|c|c|c|c|c|c|c|c|}
\hline & Guizhou & Hebei & Heilongjiang & Inner Mongolia & Jiangxi & Jilin & Liaoning \\
\hline $\operatorname{lngdp}$ & $\begin{array}{c}-0.6032 * * * \\
(0.1658)\end{array}$ & $\begin{array}{c}0.1231 \\
(0.0922)\end{array}$ & $\begin{array}{c}-0.8851 * * * \\
(0.0567)\end{array}$ & $\begin{array}{c}-0.4689^{* * *} \\
(0.1232)\end{array}$ & $-0.7984^{* * *}$ & $\begin{array}{c}-0.105 \\
(01152)\end{array}$ & $-1.3088^{* * *}$ \\
\hline \multirow{2}{*}{$\mathrm{RD}$} & $\begin{array}{l}(0.1658) \\
1.1946 \text { * }\end{array}$ & $\begin{array}{c}(0.0922) \\
-0.1778\end{array}$ & & $\begin{array}{c}(0.1232) \\
0.4819\end{array}$ & $\begin{array}{c}(0.0814) \\
9.9568 * * *\end{array}$ & $\begin{array}{r}(0.1152) \\
-0.6175\end{array}$ & $(0.2768)$ \\
\hline & $\begin{array}{c}1.1946 \text { * } \\
(0.66)\end{array}$ & $\begin{array}{c}-0.1778 \\
(0.7938)\end{array}$ & $\begin{array}{c}-2.5627^{* * *} \\
(0.3372)\end{array}$ & $\begin{array}{l}0.4819 \\
(0.398)\end{array}$ & $\begin{array}{c}9.9568^{* * *} \\
(3.0815)\end{array}$ & $\begin{array}{l}-0.6175 \\
(1.4708)\end{array}$ & $\begin{array}{c}1.6168^{* *} \\
(0.7488)\end{array}$ \\
\hline \multirow[t]{2}{*}{ MAN } & -0.2773 & 0.0670 * & $-1.5791^{* * *}$ & 0.3353 & -0.2658 & $-1.0779^{* * *}$ & $0.5017^{* * *}$ \\
\hline & $(0.4198)$ & $(0.0396)$ & $(0.2801)$ & $(0.3675)$ & $(0.4454)$ & $(0.3707)$ & $(0.134)$ \\
\hline \multirow[t]{2}{*}{ EDU } & 0.3981 & 0.5793 & $-0.6885^{* *}$ & 0.0314 & 0.1441 & $2.9109 * *$ & $-2.3315^{* * *}$ \\
\hline & $(0.5579)$ & $(0.5552)$ & $(0.2966)$ & $(0.4823)$ & $(1.0585)$ & $(1.2058)$ & $(0.3227)$ \\
\hline \multirow[t]{2}{*}{ NAT } & -0.3331 & $0.2948 * *$ & $1.3058^{* * *}$ & 0.0003 & $0.9188^{* * *}$ & $0.6607^{* * *}$ & 0.0593 \\
\hline & $(0.3679)$ & $(0.1384)$ & $(0.2236)$ & $(0.2342)$ & $(0.1515)$ & $(0.1609)$ & $(0.208)$ \\
\hline \multirow[t]{2}{*}{ FDI } & 0.001 & 0.0339 * & 0.0318 & $0.2695^{* * *}$ & $0.3983^{* * *}$ & 0.3763 & -0.0072 \\
\hline & $(0.0185)$ & $(0.0191)$ & $(0.0302)$ & $(0.0909)$ & $(0.0876)$ & $(0.3868)$ & $(0.0063)$ \\
\hline \multirow[t]{2}{*}{ INV } & 0.0131 & -0.0013 & $0.0368^{* * *}$ & $0.0082 * *$ & -0.0005 & $0.0353 * * *$ & $0.0187^{* * *}$ \\
\hline & $(0.0119)$ & $(0.0014)$ & $(0.0052)$ & $(0.0034)$ & $(0.0215)$ & $(0.0119)$ & $(0.0023)$ \\
\hline \multirow[t]{3}{*}{ CONS } & $2.3398^{* * *}$ & -0.6973 * & $3.2495^{* * *}$ & 0.9181 & $1.8274^{* * *}$ & 0.3677 & $5.2157^{* * *}$ \\
\hline & $(0.7705)$ & $(0.359)$ & $(0.313)$ & $(0.6773)$ & $(0.4848)$ & $(0.58)$ & $(1.2465)$ \\
\hline & Ningxia & Qinghai & Shaanxi & Shandong & Shanxi & Xinjiang & Yunnan \\
\hline \multirow[t]{2}{*}{$\operatorname{lngdp}$} & $-0.1244 * * *$ & -0.1035 & -0.0113 & $-0.3335^{* * *}$ & -0.2538 & $-1.2393^{* * *}$ & $-1.1953^{* * *}$ \\
\hline & $(0.0398)$ & $(0.0633)$ & $(0.0546)$ & $(0.0395)$ & $(0.1584)$ & $(0.08)$ & $(0.0726)$ \\
\hline \multirow[t]{2}{*}{$\mathrm{RD}$} & 0.2971 & $1.5658^{* * *}$ & $-1.1960^{* * *}$ & 0.6988 & $1.9737^{* * *}$ & $2.6450^{* * *}$ & $8.7009^{* * *}$ \\
\hline & $(0.4213)$ & $(0.2263)$ & $(0.3404)$ & $(0.6543)$ & $(0.3965)$ & $(0.1947)$ & (1.1314) \\
\hline \multirow[t]{2}{*}{ MAN } & $-2.2052 * * *$ & $-0.2765^{* * *}$ & $-1.5960^{* * *}$ & $-0.3371^{* * *}$ & $2.0167^{* * *}$ & 0.0142 & $-3.6497^{* * *}$ \\
\hline & $(0.2469)$ & $(0.0326)$ & $(0.1757)$ & $(0.0489)$ & $(0.7251)$ & $(0.163)$ & $(0.3889)$ \\
\hline \multirow[t]{2}{*}{ EDU } & $4.6619^{* * *}$ & 0.2714 & -0.005 & -0.2639 & $1.8149^{* * *}$ & $1.4490 * * *$ & $-6.4311^{* * *}$ \\
\hline & $(0.8919)$ & $(0.2055)$ & $(0.1943)$ & $(0.3403)$ & $(0.6348)$ & $(0.1562)$ & $(0.8099)$ \\
\hline \multirow[t]{2}{*}{ NAT } & -0.0188 & -0.1303 & $-0.3261^{* * *}$ & $3.3748^{* * *}$ & $0.6943^{*}$ & $0.6609^{* * *}$ & $4.5236^{* * *}$ \\
\hline & $(0.2243)$ & $(0.1497)$ & $(0.0923)$ & $(0.2859)$ & $(0.3552)$ & $(0.0969)$ & $(0.4365)$ \\
\hline \multirow[t]{2}{*}{ FDI } & $-0.3880^{* * *}$ & $-0.4756^{* * *}$ & 0.0009 & $-0.0091^{* *}$ & -0.001 & 0.014 & $0.9018^{* * *}$ \\
\hline & $(0.0666)$ & $(0.1372)$ & $(0.0025)$ & $(0.0045)$ & $(0.0078)$ & $(0.0272)$ & $(0.1755)$ \\
\hline \multirow[t]{2}{*}{ INV } & -0.0021 & -0.0219 * & $-0.0047^{* *}$ & $0.0278^{* * *}$ & $0.0115^{*}$ & $0.0405^{* * *}$ & $-0.0470 * * *$ \\
\hline & $(0.0032)$ & $(0.0133)$ & $(0.002)$ & $(0.0029)$ & $(0.0061)$ & $(0.003)$ & $(0.0171)$ \\
\hline \multirow[t]{2}{*}{ CONS } & $1.9152^{* * *}$ & $0.3789^{* *}$ & $1.5202 * * *$ & $0.7603^{* * *}$ & -1.2683 & $3.6804^{* * *}$ & $3.9790 * * *$ \\
\hline & $(0.3238)$ & $(0.1707)$ & $(0.2236)$ & $(0.1506)$ & $(1.0085)$ & $(0.2805)$ & $(0.2917)$ \\
\hline
\end{tabular}

Standard errors in parentheses. ${ }^{* *}, * *$, and ${ }^{*}$ indicate a $1 \%, 5 \%$, and $10 \%$ level of significance, respectively. CONS refers to constant. 


\subsubsection{Time Prediction}

In a highly energy-dependent economy, energy resources' exploitation would even cause declination in GDP in the long run [13]. To identity whether reliance on energy resources will lead to the economic recession, this paper introduces the time prediction method. It can also provide a criterion for further classification analysis. This paper derives the prediction model from Equation (1) based on the above SUR estimation results. The derivation process is as follows. First, we rewrite Equation (1):

$$
\begin{gathered}
\ln \left(Y_{i 1}\right)-\ln \left(Y_{i 0}\right)=\beta_{i 0}+\beta_{i 1} \ln \left(Y_{i 0}\right)+\beta_{i 2} R D_{i}+\beta_{i 3} Z_{i}+\varepsilon_{i} \\
\ln \left(Y_{i 1}\right)=\beta_{i 0}+\left(\beta_{i 1}+1\right) \ln \left(Y_{i 0}\right)+\beta_{i 2} R D_{i}+\beta_{i 3} Z_{i}+\varepsilon_{i}
\end{gathered}
$$

where $Y_{i t}$ represents the GDP of each province in year $t$. To assess the long-term effects of $R D$ and $Z$ on economic growth, we assume that $R D$ and $Z$ are both increased by a standard deviation in the base period. Thus, we have:

$$
E\left(\Delta \ln \left(Y_{1, i}\right)\right)=\beta_{i 2} \Delta R D_{i}+\beta_{i 3} \Delta Z_{i}
$$

After two periods, the income gap is equal to:

$$
\begin{gathered}
E\left(\Delta \ln \left(Y_{2, i}\right)\right)=\left(\beta_{i 1}+2\right)\left(\beta_{i 2} \Delta R D_{i}+\beta_{i 3} \Delta Z_{i}\right) \\
E\left(\Delta \ln \left(Y_{2, i}\right) / Y_{2, i}\right)=\exp \left(\left(\beta_{i 1}+2\right)\left(\beta_{i 2} \Delta R D_{i}+\beta_{i 3} \Delta Z_{i}\right)\right)-1
\end{gathered}
$$

After three periods, we have:

$$
\begin{gathered}
E\left(\Delta \ln \left(Y_{3, i}\right)\right)=\left(1+\left(\beta_{i 1}+1\right)+\left(\beta_{i 1}+1\right)^{2}\right)\left(\beta_{i 2} \Delta R D_{i}+\beta_{i 3} \Delta Z_{i}\right) \\
E\left(\Delta \ln \left(Y_{3, i}\right) / Y_{3, i}\right)=\exp \left(\left(1+\left(\beta_{i 1}+1\right)+\left(\beta_{i 1}+1\right)^{2}\right)\left(\beta_{i 2} \Delta R D_{i}+\beta_{i 3} \Delta Z_{i}\right)\right)-1
\end{gathered}
$$

Since $-1<\beta_{i 1}+1<1$, as $t$ approaches infinity, the first term on the right-hand side converges to:

$$
\lim _{t \rightarrow \infty}\left(1+\left(\beta_{i 1}+1\right)+\left(\beta_{i 1}+1\right)^{2}+\ldots+\left(\beta_{i 1}+1\right)^{t-1}\right)=-1 / \beta_{i 1}
$$

Then we have:

$$
E \Delta \ln \left(Y_{i, \infty}\right)=-\left(\frac{\beta_{i 2}}{\beta_{i 1}}\right) \Delta R D-\left(\frac{\beta_{i 3}}{\beta_{i 1}}\right) \Delta Z
$$

Taking exponentials on both sides, we can calculate the change in long-term GDP percentage:

$$
E\left(\frac{\Delta Y_{i, \infty}}{Y_{i, \infty}}\right)=\exp \left[-\left(\frac{\beta_{i 2}}{\beta_{i 1}}\right) \Delta R D-\left(\frac{\beta_{i 3}}{\beta_{i 1}}\right) \Delta Z\right]-1
$$

$-\left(\frac{\beta_{i 2}}{\beta_{i 1}}\right)$ and $-\left(\frac{\beta_{i 3}}{\beta_{i 1}}\right)$ respectively reflect the long-term income effect caused by the change of resource dependence and the income effect caused by the change of other explanatory variables. This model means that, all other things being equal, if the degree of resource dependence is increased by one standard deviation in the base period, how much change of GDP percentage will be caused. Table 5 shows the result of the time prediction.

The result shows that if the energy resource dependence degree is increased by one standard deviation in the base period, the economy of provinces will eventually experience negative growth. Such provinces are Heilongiiang, Liaoning, Ningxia, Qinghai, Shaanxi, and Xinjiang.

To test the reliability of the model, this study increases the resource dependence by 0.5 standard deviation and 2 standard deviation respectively, by controlling other conditions. The results show that the provinces that would eventually experience negative economic growth are still Heilongjiang, Liaoning, Ningxia, Qinghai, Shaanxi, and Xinjiang. This verifies the reliability of the model. 
Table 5. The time prediction.

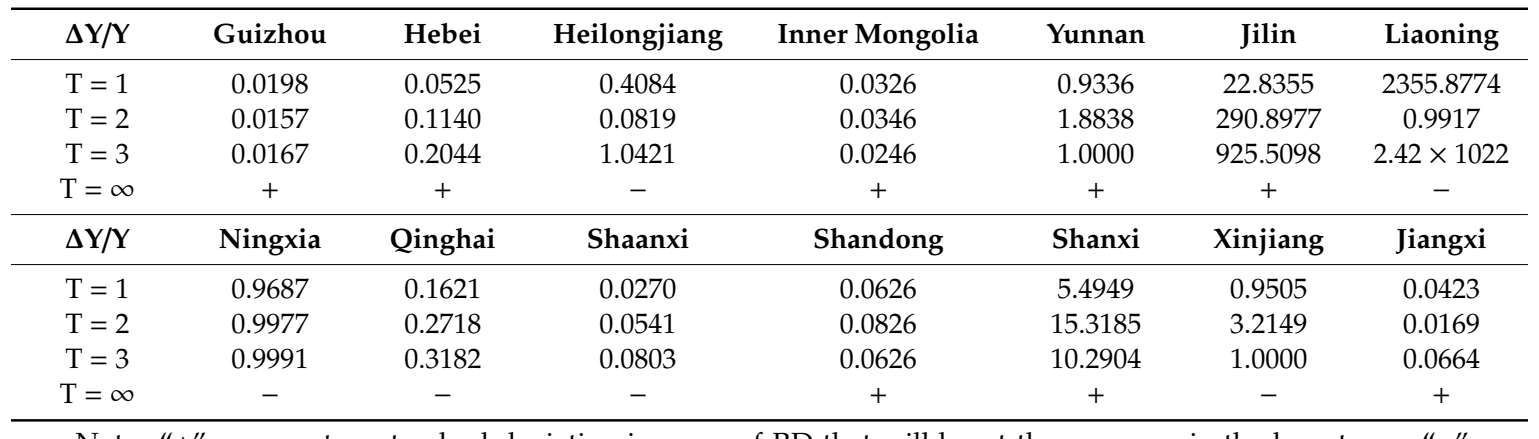

Note: " + " represents a standard deviation increase of RD that will boost the economy in the long term. "-" represents that the economy will suffer from recession in the long term.

\subsection{Transmission Channels of the Energy Resource Curse}

\subsubsection{Regressions for Five Transmission Variables}

In the overall regression, we believe that the inconsistency between the regression results and the reality is due to the heterogeneity of provinces. To further explore the specific situation, this study analyzes whether the energy resource dependence has an impact on economic development through indirect transmission channels. The coefficient of $R D$ in Equation (1) only reflects the direct impact of energy resource dependence on the economic growth of provinces. The following part proceeds to evaluate possible indirect impacts by two steps. The first step is to evaluate Equation (13) to find the relationships between energy resources and five control variables (INV, FDI, NAT, MAN, and EDU). For the second step, we calculate the overall impact of energy resources on economic growth by substituting Equation (13) into (1).

Equation (13) shows the specification of the relationship between all the control variables on RD. In this equation, $Z_{i t}$ represents the five control variables and $\alpha_{1}$ is the impact of energy resource dependence on $Z_{i t}$. Through this equation, we can investigate the indirect impact of energy resource dependency on economic growth through five transmission channels:

$$
Z_{i t}=\alpha_{i 0}+\alpha_{i 1} R D_{i t}+\epsilon_{i t}
$$

Given the potential crowding-out effects, the coefficients of INV, EDU, MAN, and FDI in Equation (13) are expected to be negative. In addition, a high level of nationalization usually restrains economic growth. The energy resource dependence can raise the levels of nationalization and exacerbate nationalization's negative impact on economic growth. The energy resources curse can be realized indirectly. Therefore, NAT's coefficient in Equation (13) is also expected to be negative. Table 6 shows the results of Equation (13). 
Table 6. Regressions for transmission channels.

\begin{tabular}{|c|c|c|c|c|c|c|c|}
\hline & Guizhou & Hebei & Heilongjiang & Inner Mongolia & Jiangxi & Jilin & Liaoning \\
\hline & \multicolumn{7}{|c|}{ Coefficients of $R D$} \\
\hline MAN & $\begin{array}{c}-1.3333^{* * * *} \\
(0.098)\end{array}$ & $\begin{array}{c}-1.581 \\
(1.3577)\end{array}$ & $\begin{array}{c}-2.5863^{* * *} \\
(0.1576)\end{array}$ & $\begin{array}{c}-0.5561 * * * \\
(0.0966)\end{array}$ & $\begin{array}{c}-2.5590^{* * *} \\
(0.7387)\end{array}$ & $\begin{array}{c}-2.8196^{* * *} \\
(0.2693)\end{array}$ & $\begin{array}{c}-2.8565^{* * *} \\
(0.4332)\end{array}$ \\
\hline INV & $\begin{array}{c}17.2957^{* * *} \\
(2.5392)\end{array}$ & $\begin{array}{c}-5.9578 \\
(11.0408)\end{array}$ & $\begin{array}{c}-9.3884^{* * *} \\
(2.4879)\end{array}$ & $\begin{array}{c}81.8762 * * * \\
(4.9927)\end{array}$ & $\begin{array}{c}60.7413^{* * * *} \\
(5.0383)\end{array}$ & $\begin{array}{c}31.5536^{* * *} \\
(4.4188)\end{array}$ & $\begin{array}{c}-179.3170^{* * *} \\
(31.5321)\end{array}$ \\
\hline NAT & $\begin{array}{c}-0.5839 * * * \\
(0.0741)\end{array}$ & $\begin{array}{c}-0.6205^{* * *} \\
(0.1106)\end{array}$ & $\begin{array}{c}3.9820 * * * \\
(0.1314)\end{array}$ & $\begin{array}{c}-1.9672 * * * \\
(0.1721)\end{array}$ & $\begin{array}{c}-10.9548^{* * *} \\
(0.4127)\end{array}$ & $\begin{array}{c}6.1432 * * * \\
(0.3963)\end{array}$ & $\begin{array}{c}5.9867^{* * * *} \\
(0.3462)\end{array}$ \\
\hline FDI & $\begin{array}{c}0.2982 \\
(1.0605)\end{array}$ & $\begin{array}{l}1.4364^{*} \\
(0.8262)\end{array}$ & $\begin{array}{c}2.5821 * * * \\
(0.4856)\end{array}$ & $\begin{array}{c}4.5964^{* * *} \\
(0.0857)\end{array}$ & $\begin{array}{c}-16.0394^{* * *} \\
(1.9162)\end{array}$ & $\begin{array}{c}-0.4227^{*} \\
(0.2233)\end{array}$ & $\begin{array}{c}82.9098^{* * * *} \\
(7.9436)\end{array}$ \\
\hline \multirow[t]{3}{*}{ EDU } & $\begin{array}{l}-0.0187 \\
(0.0317)\end{array}$ & $\begin{array}{c}-1.3897^{* * *} \\
(0.0576)\end{array}$ & $\begin{array}{c}-0.9344^{* * *} \\
(0.0432)\end{array}$ & $\begin{array}{c}0.0373 \\
(0.0486)\end{array}$ & $\begin{array}{l}-0.1428 \\
(0.1681)\end{array}$ & $\begin{array}{c}-1.3246^{* * *} \\
(0.1565)\end{array}$ & $\begin{array}{c}-2.7461^{* * *} \\
(0.2313)\end{array}$ \\
\hline & Ningxia & Qinghai & Shaanxi & Shandong & Shanxi & Xinjiang & Yunnan \\
\hline & \multicolumn{7}{|c|}{ Coefficients of $R D$} \\
\hline MAN & $\begin{array}{c}-0.4166^{* * *} \\
(0.1152)\end{array}$ & $\begin{array}{c}-1.6240^{* * *} \\
(0.5458)\end{array}$ & $\begin{array}{c}-1.4795^{* * *} \\
(0.1523)\end{array}$ & $\begin{array}{c}-7.1750 * * * \\
(0.3296)\end{array}$ & $\begin{array}{c}-0.6118^{* * *} \\
(0.0675)\end{array}$ & $\begin{array}{c}-0.8643^{* * *} \\
(0.0662)\end{array}$ & $\begin{array}{c}1.0184^{* * *} \\
(0.254)\end{array}$ \\
\hline INV & $\begin{array}{c}-60.4498^{* * * *} \\
(6.8834)\end{array}$ & $\begin{array}{c}-26.3971^{* * * *} \\
(2.2788)\end{array}$ & $\begin{array}{c}-21.2090^{* * * *} \\
(6.7456)\end{array}$ & $\begin{array}{c}49.8928^{* * *} \\
(4.2262)\end{array}$ & $\begin{array}{c}28.2422^{* * *} \\
(1.3609)\end{array}$ & $\begin{array}{c}-39.4177^{* * * *} \\
(1.8962)\end{array}$ & $\begin{array}{c}35.3213^{* * *} \\
(5.4782)\end{array}$ \\
\hline NAT & $\begin{array}{c}-0.6788^{* * *} \\
(0.0614)\end{array}$ & $\begin{array}{c}3.3701^{* * * *} \\
(0.1178)\end{array}$ & $\begin{array}{c}1.4192^{* * *} \\
(0.2634)\end{array}$ & $\begin{array}{c}1.1068^{* * *} \\
(0.0708)\end{array}$ & $\begin{array}{c}-0.6542^{* * *} \\
(0.0361)\end{array}$ & $\begin{array}{c}1.5628^{* * *} \\
(0.0705)\end{array}$ & $\begin{array}{c}-1.3251^{* * *} \\
(0.1522)\end{array}$ \\
\hline FDI & $\begin{array}{c}-1.4520 * * * \\
(0.3967)\end{array}$ & $\begin{array}{c}1.8067^{* * *} \\
(0.0687)\end{array}$ & $\begin{array}{c}15.9627^{* *} \\
(7.6268)\end{array}$ & $\begin{array}{c}61.7851 * * * \\
(4.2314)\end{array}$ & $\begin{array}{c}2.5709 \\
(3.3508)\end{array}$ & $\begin{array}{c}5.4621 * * * \\
(0.3823)\end{array}$ & $\begin{array}{c}-1.0416^{*} \\
(0.6083)\end{array}$ \\
\hline EDU & $\begin{array}{c}-0.1347^{* * *} \\
(0.022)\end{array}$ & $\begin{array}{c}-0.4757^{* * *} \\
(0.0462)\end{array}$ & $\begin{array}{c}-0.1379 * \\
(0.0788)\end{array}$ & $\begin{array}{c}-1.1306^{* * *} \\
(0.0475)\end{array}$ & $\begin{array}{l}0.0503 * \\
(0.0265)\end{array}$ & $\begin{array}{c}-0.2268^{* * *} \\
(0.0271)\end{array}$ & $\begin{array}{c}0.4678^{* * *} \\
(0.0544)\end{array}$ \\
\hline
\end{tabular}

Standard errors in parentheses. ${ }^{* * *}, * *$, and ${ }^{*}$ indicate a $1 \%, 5 \%$, and $10 \%$ level of significance, respectively. 
The above results show that RD does have a certain impact on all five variables, but the levels of significance are various in different provinces. To explain the regression results in detail, this study takes these five-channel variables as benchmarks for analysis.

When considering the impact of RD on MAN, the coefficients of RD in most provinces are significantly positive. Specifically, the coefficient of RD in Hebei province is the only one which is not significant, while the coefficient of RD in other provinces is significant and negative. Among those being significant, only RD's coefficient of Yunnan province is positive. This confirms the previous hypothesis that energy resource dependence would have a crowding-out effect on the manufacturing industry. This effect is quite common in energy resource-abundant provinces in China. It is probably because the relatively heavy investment of the exploitation industry limits the input of other industries, and such transfer of capital and labor between industries weakens the manufacturing and related technical service industries. Since those industries are the cradle of technological innovation and entrepreneurial growth in industrialization, their decline inevitably causes a fatal blow to economic growth [73]. Thus, dependence on energy resources can trigger the resource curse by inhibiting the development of manufacturing, which often hinders economic development, eventually.

When considering the impact of RD on INV, the coefficient of RD in most provinces is significant, but the signs of the coefficients blur. INV is quite similar to MAN in terms of significance, except that the coefficient of RD in Hebei province is not significant. Among the 14 significant coefficients, 6 of them are negative and the other 8 are positive. This shows that variable RD has different impacts on INV in different provinces. Dependency on energy resources theoretically has a crowding-out effect on investment, but the abundance of energy resources can also attract investment. The interaction between the two forces in opposite directions would produce different results in various provinces.

For the 6 provinces with negative coefficients of RD, energy resource dependency has a crowdingout effect on investment. The availability of abundant energy resources provides a stable source of energy resource income and reduces the economy's dependence on manufacturing capital and demand for investment. Moreover, energy resources have a higher elasticity of demand and lower elasticity of supply, which means that they can be easily replaced. Their high price volatility increases investment risk and deters domestic and international private investors.

The coefficients of RD for NAT in all observed provinces are significant, but the signs of the coefficients are not uniform. This means a close relationship between energy resources and the state-owned economy. In China, governments usually allocate energy resources and favor state-owned enterprises. Compared with private enterprises, state-owned enterprises tend to have advantages in competing for the rights of energy resource exploitation [74]. However, the results show that the coefficient of RD is significantly positive in 7 provinces and significantly negative in the other 7 provinces. Those negative coefficients are due to these provinces having many state-owned exploitation enterprises in areas where energy resources are exhausted. These state-owned enterprises having limited energy resources for exploitation and have to dismiss large numbers of employees. This would seriously cripple the economic growth $[10,75]$.

In terms of the volume of FDI, the coefficient of RD in all provinces except Guizhou and Shanxi is significant, but the signs of the coefficients blur. Those negative coefficients show that the energy exploitation industries in Guizhou and Shanxi provinces do exclude foreign direct investment. Among the 12 provinces with significant coefficients, the RD's coefficients of 4 provinces are significantly negative. According to the Negative List of China's Access to Foreign Investment 2018, those negative coefficients are due to the state's vigilance and restrictions on foreign capital in the exploitation industry. By contrast, the coefficients of RD in the other 8 provinces are significantly positive. It indicates that the energy exploitation industries in these provinces attract foreign direct investment.

In terms of the influence of RD on EDU, the EDU's coefficients of 9 provinces are significant, and the signs of them are all negative, except that of Yunnan. The negative coefficients indicate that energy resource dependency has a common crowding-out effect on talents [76,77]. Sachs and Warner suggest that dependence on energy resources would generate overconfidence because coming to be 
rich easily leads to laziness [19]. Primary industries such as energy exploitation do not need a very well-educated labor force. Hence, the government has little incentive to strengthen education.

\subsubsection{Classification Analysis}

As stated above, energy resource abundance explains variation in different transmission channel variables. To evaluate the direct and indirect impact of energy resources on economic growth, we substitute Equation (13) into (1) and obtain Equation (14):

$$
g_{i t}=\left(\beta_{i 0}+\alpha_{i 0} \beta_{i 3}\right)+\beta_{i 1} \ln \left(g d p_{i, t-1}\right)+\left(\beta_{i 2}+\alpha_{i 1} \beta_{i 3}\right) R D_{i t}+\beta_{i 3} \epsilon_{i t}+\varepsilon_{i t}
$$

where $\beta_{i 2} R D_{i t}$ is the direct impact of $\mathrm{RD}$ on economic growth, $\alpha_{i 1} \beta_{i 3} R D_{i t}$ represents the indirect impact of $\mathrm{RD}$ on economic growth through transmission channels, and $\left(\beta_{i 2}+\alpha_{i 1} \beta_{i 3}\right) R D_{i t}$ measures the overall impact of energy resources on economic growth.

By assessing the effects of each channel variable in the observed provinces on economic growth, we could measure the overall effects of energy resources on economic development in each province. Table 7 includes the results.

Table 7. The relative importance of transmission channels.

\begin{tabular}{|c|c|c|c|c|c|}
\hline Province & Transmission Channel & $\alpha 1$ & $\beta 3$ & $\alpha 1 \beta 3+\beta 2$ & Relative Contribution \\
\hline \multirow[t]{2}{*}{ Guizhou } & RD & & & 1.1946 & $100.00 \%$ \\
\hline & TOTAL & & & 1.1946 & $100.00 \%$ \\
\hline \multirow[t]{5}{*}{ Hebei ** } & RD & & & -0.1778 & $-34.50 \%$ \\
\hline & MAN & -1.5810 & 0.0670 & -0.1059 & $-20.55 \%$ \\
\hline & NAT & -0.6205 & 0.2948 & -0.1829 & $-35.50 \%$ \\
\hline & FDI & 1.4364 & 0.0339 & 0.0487 & $9.45 \%$ \\
\hline & TOTAL & & & -0.4180 & $100.00 \%$ \\
\hline \multirow[t]{6}{*}{ Heilongjiang *** } & RD & & & -2.5627 & $-19.97 \%$ \\
\hline & MAN & -2.5863 & -1.5791 & 4.0840 & $31.82 \%$ \\
\hline & EDU & -0.9344 & -0.6885 & 0.6433 & $5.01 \%$ \\
\hline & NAT & 3.9820 & 1.3058 & 5.1997 & $40.51 \%$ \\
\hline & INV & -9.3884 & 0.0368 & -0.3455 & $-2.69 \%$ \\
\hline & TOTAL & & & 7.0189 & $100.00 \%$ \\
\hline \multirow[t]{3}{*}{ Inner Mongolia } & FDI & 4.5964 & 0.2695 & 1.2387 & $64.85 \%$ \\
\hline & INV & 81.8762 & 0.0082 & 0.6714 & $35.15 \%$ \\
\hline & TOTAL & & & 1.9101 & $100.00 \%$ \\
\hline \multirow[t]{4}{*}{ Jiangxi * } & $\mathrm{RD}$ & & & 9.9568 & $37.70 \%$ \\
\hline & NAT & -10.9548 & 0.9188 & -10.0653 & $-38.11 \%$ \\
\hline & FDI & -16.0394 & 0.3983 & -6.3885 & $-24.19 \%$ \\
\hline & TOTAL & & & -6.4970 & $100.00 \%$ \\
\hline \multirow[t]{5}{*}{ Jilin * } & MAN & -2.8196 & -1.0779 & 3.0392 & $25.19 \%$ \\
\hline & EDU & -1.3246 & 2.9109 & -3.8558 & $-31.95 \%$ \\
\hline & NAT & 6.1432 & 0.6607 & 4.0588 & $33.63 \%$ \\
\hline & INV & 31.5536 & 0.0353 & 1.1138 & $9.23 \%$ \\
\hline & TOTAL & & & 4.3561 & $100.00 \%$ \\
\hline \multirow[t]{5}{*}{ Liaoning *** } & RD & & & 1.6168 & $12.63 \%$ \\
\hline & MAN & -2.8565 & 0.5017 & -1.4331 & $-11.19 \%$ \\
\hline & EDU & -2.7461 & -2.3315 & 6.4025 & $50.00 \%$ \\
\hline & INV & -179.3170 & 0.0187 & -3.3532 & $-26.19 \%$ \\
\hline & TOTAL & & & 3.2330 & $100.00 \%$ \\
\hline
\end{tabular}


Table 7. Cont.

\begin{tabular}{|c|c|c|c|c|c|}
\hline Province & Transmission Channel & $\alpha 1$ & $\beta 3$ & $\beta 2+\alpha 1 \beta 3$ & Relative Contribution \\
\hline \multirow[t]{4}{*}{ Ningxia *** } & MAN & -0.4166 & -2.2052 & 0.9187 & $43.54 \%$ \\
\hline & EDU & -0.1347 & 4.6619 & -0.6280 & $-29.76 \%$ \\
\hline & FDI & -1.4520 & -0.3880 & 0.5634 & $26.70 \%$ \\
\hline & TOTAL & & & 0.8541 & $100.00 \%$ \\
\hline \multirow[t]{5}{*}{ Qinghai *** } & RD & & & 1.5658 & $45.36 \%$ \\
\hline & MAN & -1.6240 & -0.2765 & 0.4490 & $13.01 \%$ \\
\hline & FDI & 1.8067 & -0.4756 & -0.8593 & $-24.89 \%$ \\
\hline & INV & -26.3971 & -0.0219 & 0.5781 & $16.75 \%$ \\
\hline & TOTAL & & & 1.7337 & $100.00 \%$ \\
\hline \multirow[t]{5}{*}{ Shaanxi *** } & RD & & & -1.1960 & $-29.03 \%$ \\
\hline & MAN & -1.4795 & -1.5960 & 2.3613 & $57.32 \%$ \\
\hline & NAT & 1.4192 & -0.3261 & -0.4628 & $-11.23 \%$ \\
\hline & INV & -21.2090 & -0.0047 & 0.0997 & $2.42 \%$ \\
\hline & TOTAL & & & 0.8022 & $100.00 \%$ \\
\hline \multirow[t]{5}{*}{ Shandong * } & MAN & -7.1750 & -0.3371 & 2.4187 & $29.85 \%$ \\
\hline & NAT & 1.1068 & 3.3748 & 3.7352 & $46.10 \%$ \\
\hline & FDI & 61.7851 & -0.0091 & -0.5622 & $-6.94 \%$ \\
\hline & INV & 49.8928 & 0.0278 & 1.3870 & $17.12 \%$ \\
\hline & TOTAL & & & 6.9787 & $100.00 \%$ \\
\hline \multirow[t]{6}{*}{ Shanxi * } & RD & & & 1.9737 & $48.40 \%$ \\
\hline & MAN & -0.6118 & 2.0167 & -1.2338 & $-30.26 \%$ \\
\hline & EDU & 0.0503 & 1.8149 & 0.0913 & $2.24 \%$ \\
\hline & NAT & -0.6542 & 0.6943 & -0.4542 & $-11.14 \%$ \\
\hline & INV & 28.2422 & 0.0115 & 0.3248 & $7.96 \%$ \\
\hline & TOTAL & & & 0.7017 & $100.00 \%$ \\
\hline \multirow[t]{5}{*}{ Xinjiang *** } & RD & & & 2.6450 & $62.56 \%$ \\
\hline & EDU & -0.2268 & 1.4490 & -0.3286 & $-7.77 \%$ \\
\hline & NAT & 1.5628 & 0.6609 & 1.0329 & $24.43 \%$ \\
\hline & INV & 5.4621 & 0.0405 & 0.2212 & $5.23 \%$ \\
\hline & TOTAL & & & 3.5704 & $100.00 \%$ \\
\hline \multirow[t]{7}{*}{ Yunnan * } & RD & & & 8.7009 & $36.22 \%$ \\
\hline & MAN & 1.0184 & -3.6497 & -3.7169 & $-15.47 \%$ \\
\hline & EDU & 0.4678 & -6.4311 & -3.0085 & $-12.52 \%$ \\
\hline & NAT & -1.3251 & 4.5236 & -5.9942 & $-24.96 \%$ \\
\hline & FDI & -1.0416 & 0.9018 & -0.9393 & $-3.91 \%$ \\
\hline & INV & 35.3213 & -0.0470 & -1.6601 & $-6.91 \%$ \\
\hline & TOTAL & & & -6.6181 & $100.00 \%$ \\
\hline
\end{tabular}

Note: ${ }^{* * *}$ represents a reduction in the predicted $\mathrm{Y}$. ${ }^{* *}$ represents the situation where the coefficient of RD and the indicator TOTAL are negative, and the majority of coefficients of channel variables are negative. * represents the case where the coefficient of RD is positive, some coefficients of channel variables are negative, and the value of the indicator TOTAL is uncertain. The absence of * indicates that the province is in the energy resource blessing period.

According to the outcome in Tables 5 and 7, four groups can be defined. Group one, named as level-three energy resource curse, means the provinces in which increasing RD by one standard deviation would lead to the declination of GDP in the long term. Although the GDP of the remaining provinces would grow after increasing RD by one standard deviation, most of them are negatively affected by energy resource dependence. Given this, it is necessary to classify the rest of the provinces.

Group two are provinces whose coefficients of $\mathrm{RD}$ are significantly negative. It indicates that the effects of energy resources on the economy through transmission channels are negative, and values of TOTAL are negative. This is a level-two resource curse. Group three represents provinces whose coefficients of RD are positive or not significant but the effects of resource dependence on some transmission channels are negative. They fall under the level-one resource course. Group four includes provinces whose coefficients of RD are positive and significant, indicating that they are under "resource blessing".

There is a serious resource curse in the provinces that belong to the level-three and the level-two resource curse. The provinces of the level-three resource curse are Heilongjiang, Liaoning, Ningxia, Qinghai, Shaanxi, and Xinjiang. If these provinces increase resource dependences by one standard 
deviation, their high dependences on energy resources would lead to an economic recession in the future. Hebei belongs to the category of the level-two resource curse. Table 7 shows that energy resources have a significant direct and indirect negative impact on the economy in Hebei province. Among the indirect channels, $56.05 \%$ is the negative effect of energy resources through the two significant channels, MAN and NAT. By contrast, energy resources only contribute $9.45 \%$ to economic growth through FDI.

The level-one energy resource curse represents an "invisible energy resource curse", or minor resource curse. In this case, energy resources directly promote but indirectly hinder economic growth. Jiangxi, Jilin, Shandong, Shanxi, and Yunnan are the provinces that fall under the level-one resource curse.

Group four represents energy resource blessing. Provinces in group four are Guizhou and Inner Mongolia. In Guizhou, energy resources have a direct positive impact on economic growth and the coefficients of transmission channel variables are insignificant. In Inner Mongolia, although there is no evidence that energy resources have a significant impact on economic growth, they have an indirect positive impact on the economy through FDI and INV. Inner Mongolia is China's most important producer of rare earth. China dominates the global production of rare earth, accounting for more than $95 \%$ of the global supply before 2006 [78]. Due to the implementation of the registration and licensing system for the exploration and mining of rare earth mines in China [79], rent-seeking behavior is likely to occur, which may generate the resource curse. However, the state has taken a series of measures to restrict the mining and trade of rare earth (Interim Provisions on the Administration of Foreign Investment in Rare Earth Industry, 2002; Several Opinions of the State Council on Promoting the Sustainable and Healthy Development of the Rare Earth Industry, 2011). They alleviate the resource curse of rare earth to some extent. Inner Mongolia has a vast territory and abundant resources and there is resource blessing in Inner Mongolia in general. Table 8 lists the levels of energy resource curse and provinces are classified accordingly.

Table 8. Energy resource curse level and corresponding provinces.

\begin{tabular}{ccc}
$\begin{array}{c}\text { Level of the Energy } \\
\text { Resource Curse }\end{array}$ & Characteristics & Provinces \\
\hline $\begin{array}{c}\text { The level-three energy } \\
\text { resource curse }\end{array}$ & $\begin{array}{c}\text { Increasing RD by one standard } \\
\text { deviation would lead to the } \\
\text { declination of GDP in the long term }\end{array}$ & $\begin{array}{c}\text { Heilongjiang, Liaoning, } \\
\text { Ningxia, Qinghai, Shaanxi, } \\
\text { and Xinjiang }\end{array}$ \\
$\begin{array}{c}\text { The effects of energy resources on the } \\
\text { economy through transmission } \\
\text { resource curse }\end{array}$ & $\begin{array}{c}\text { channels are negative, and values of } \\
\text { TOTAL are negative }\end{array}$ & Hebei \\
\hline $\begin{array}{c}\text { The level-one energy } \\
\text { resource curse }\end{array}$ & $\begin{array}{c}\text { Energy resources directly promote but } \\
\text { indirectly hinder economic growth } \\
\text { "Energy resource blessing" }\end{array}$ & $\begin{array}{c}\text { Energy resources have a positive } \\
\text { impact on economic growth }\end{array}$ \\
\hline
\end{tabular}

The four groups cover China's resource curse situations. When a province first discovers abundant local energy resources, related industries would develop rapidly and thus accelerate economic growth. It is a so-called resource blessing. When the economic development reaches a cut-off point, the dependence on energy resources starts to have a negative indirect impact on the economy. This is consistent with the characteristics of the level-one resource curse. When dependence on energy resources becomes more severe, it would directly and indirectly hinder economic growth. It is consistent with the characteristics of the level-two resource curse. At its worst, a higher degree of reliance on energy resources in the future could lead to an economic recession. This situation is in line with the characteristics of the level-three resource curse. 


\subsubsection{Analysis of Invisible Energy Resource Curse}

Since the level-one energy resource curse is regarded as an "invisible energy resource curse", it is necessary to investigate the mechanism of the energy resource curse in these provinces.

In Jiangxi, the development of the state-owned economy and the introduction of foreign direct investment act as stimulators to economic development. However, the dependence on energy resources slows them both down. That is how the resource curse comes into existence.

For Jilin, the manufacturing industry with a simple structure is not conducive to economic development. Education, state-owned economy, and social fixed asset investment are beneficial to the economy. The energy resource dependence of Jilin province has a crowding-out effect on the manufacturing industry and high-quality labor force. While promoting state-owned economy and social fixed asset investment, these two opposing forces cancel each other out and the final result is that energy resource dependency is beneficial for economic growth.

In Shandong province, the dependence on energy resources has a crowding-out effect on the low-end manufacturing industry, and it also promotes the growth of the state-owned economy, foreign direct investment, and social fixed asset investment. Therefore, Shandong's energy resources and resource exploitations bring about economic growth. The booming energy industry plays a key role in transforming the Shandong economy from agriculture to modern industry. It allows Shandong to take full advantage of its abundant energy resources [80].

Shanxi's dependence on energy resources has a crowding-out effect on the manufacturing industry. It is also detrimental to the development of the state-owned economy, and because the manufacturing industry and the state-owned economy seem to affect economic growth positively, the overall impact on economic growth is negative. This indicates that the strategy of Central China Development had a limited impact on the development of the coal resource economy in Shanxi Province. It needs more time to exert a substantive impact on the economy. For example, Shanxi Province implemented the coal resource integration strategy in 2008. It reduces the coal resource use intensity, which might affect the local economy in the short term but would inevitably improve the efficiency of utilization of coal resources in the long term and bring about economic growth. Therefore, we believe that the Shanxi economy could eventually break the "energy resource curse". In addition, there is an increasingly positive influence of institutional variables on the economic development of Shanxi Province, as can be seen from the results.

For Yunnan province, manufacturing, education level, and investment have negative effects on economic development. State-owned economy and foreign direct investment would promote economic growth. Yunnan's dependence on energy resources could crowd out foreign direct investment and the development of the state-owned economy. Therefore, the development of Yunnan's resource industry would hinder economic growth through indirect negative effects.

\subsection{Energy Types and Resource Curse}

Among the many types of natural energy resources, coal, crude oil, and natural gas occupy an important position. To investigate whether different types of energy have different effects on the level of the resource curse, this paper researches the above three types of energy, respectively. According to China's Industrial Classification for National Economic Activities (1994, 2002, 2011), the mining industry is subdivided into multiple industries, such as coal mining and washing, and oil and natural gas mining. Oil mining and natural gas mining belong to the same industry. This paper defines $R D 1_{i t}$ as the proportion of fixed asset investment in the coal mining and washing industry in the total fixed-asset investment, and we define $R D 2_{i t}$ as the proportion of fixed asset investment in oil and natural gas mining in the total fixed-asset investment. These two variables represent the dependence on coal resources and the dependence on oil and natural gas resources, respectively. This paper replaces $R D_{i t}$ with $R D 1_{i t}$ and $R D 2_{i t}$, and substitutes them respectively into Equations (1)-(14) to obtain the resource curse level of each province. Table 9 shows the results. 
Table 9. Energy resource curse level of different resource types.

\begin{tabular}{|c|c|c|c|c|}
\hline Provinces & $\begin{array}{c}\text { Resource } \\
\text { Levels of Coal }\end{array}$ & $\begin{array}{l}\text { Curse Transmission } \\
\text { Channels of Coal }\end{array}$ & $\begin{array}{c}\text { Resource Levels of } \\
\text { Crude Oil and } \\
\text { Natural Gas }\end{array}$ & $\begin{array}{c}\text { Curse Transmission } \\
\text { Channels of Oil and } \\
\text { Natural Gas }\end{array}$ \\
\hline Guizhou & "Blessing" & 1 & Level-three & Direct, MAN, NAT \\
\hline Hebei ** & "Blessing" & 1 & "Blessing" & I \\
\hline Heilongjiang *** & Level-two & direct & Level-three & INV \\
\hline Inner Mongolia & "Blessing" & l & Level-one & MAN \\
\hline Jiangxi * & Level-three & MAN, FDI, INV & Level-one & MAN, NAT \\
\hline Jilin * & Level-one & NAT & Level-three & INV \\
\hline Liaoning *** & Level-three & MAN, INV & Level-three & MAN, INV \\
\hline Ningxia $* * *$ & Level-three & EDU & Level-three & MAN, FDI \\
\hline Qinghai *** & Level-one & MAN, FDI & "Blessing" & 1 \\
\hline Shaanxi *** & Level-two & direct, EDU & Level-three & NAT, INV \\
\hline Shandong* & Level-one & FDI & "Blessing" & 1 \\
\hline Shanxi * & Level-one & MAN, NAT & Level-one & MAN \\
\hline Xinjiang *** & Level-one & MAN, NAT, FDI & Level-three & MAN, EDU, INV \\
\hline Yunnan * & Level-one & MAN, EDU, NAT, FDI & Level-one & Direct, MAN \\
\hline
\end{tabular}

Note: ${ }^{* * *}$ represents a reduction in the predicted $\mathrm{Y}$. ${ }^{* *}$ represents the situation where the coefficient of $\mathrm{RD}$ and the indicator TOTAL are negative, and the majority of coefficients of channel variables are negative. * represents the case where the coefficient of RD is positive, some coefficients of channel variables are negative, and the value of the indicator TOTAL is uncertain. The absence of * indicates that the province is in the energy resource blessing period.

Heilongjiang, Liaoning, Ningxia, Shaanxi, and Xinjiang, which are under the level-three resource curse, still experience severe coal or oil-gas resource curses (level two or three). Surprisingly, Qinghai, which suffers from the level-three resource curse, has a coal resource curse of level-one, and oil-gas resource blessing. Similarly, Hebei, which experiences the level-two resource curse, is under coal resource blessing and oil-gas blessing. The natural resource structure of the two provinces can explain this phenomenon. Qinghai has a vast territory and rich types of mineral resources. By the end of 2016, 127 minerals had been discovered, of which, 55 mineral reserves were among the top 10 reserves in China. Hebei has 59 kinds of mineral reserves in the top 10 in China. However, coal reserve in Hebei only ranks 12 in China, and the ranks of crude oil and natural gas reserve are even lower. Therefore, the resource curse of Qinghai and Hebei Province may be due to other mineral resources. It is also worth noting that Guizhou Province, which is under resource blessing, has a level-three curse on oil-gas resources. Guizhou's oil and gas exploitation only accounts for a small part of its resource exploitation. From 2001 to 2016, the average $R D 2_{i t}$ in Guizhou was only $0.5 \%$, while the average $R D_{i t}$ reached $6.4 \%$. Therefore, although Guizhou has a level-three oil-gas resource curse, in general, Guizhou is still in the stage of resource blessing.

From the perspective of transmission channels, we have noticed that among the 11 provinces cursed by coal resources, 6 are related to MAN, and among the 11 provinces cursed by oil-gas resources, 8 are related to MAN. It indicates that Dutch disease is a major feature of the resource curse.

\section{Conclusions and Policy Implications}

The present study investigated 14 resource-abundant provinces and conducted panel regressions of the provinces' energy resource dependency over the period from 2001 to 2016 to test the resource curse hypothesis. It identified the relationships between their transmission channels and economic growth. Then, it used SUR technology to make a regression analysis for each province and make short-term and long-term predictions based on the time prediction model. It further analyzed the 
transmission channels of each province and classified them to explain the diversity of the energy resource curse.

Regarding the energy-abundant provinces as a whole, there is no resource curse in these regions. However, this is contrary to reality. Therefore, we analyzed the provinces respectively. This study showed that the energy resource curse is mainly realized through five indirect channels, including manufacturing, education level, nationalization, foreign direct investment, and social fixed asset investment. In different provinces, energy resource dependence affects the economy through different indirect channels. According to the outcome of time prediction, it finds that if the degree of energy resource dependence of some provinces increases by one standard deviation, the dependence on energy resources would lead to the economic recession.

Based on the analysis results of the provinces, this paper classified all the provinces into 4 groups according to our criterion. Among the 14 provinces, only 2 of them (Guizhou and Inner Mongolia) experience the energy resource blessing, 6 of them (Heilongjiang, Liaoning, Ningxia, Qinghai, Shanxi, and Xinjiang) experience the level-three energy resource curse, 1 of them (Hebei) has the level-two energy resource curse, and 5 of them (Jiangxi, Jilin, Shandong, Shaanxi, and Yunnan) fall under the level-one energy resource curse.

For the provinces under the level-there energy resource curse or the level-two energy resource curse, our policy prescription is to change the local industrial structure to reduce their dependence on energy resources. For provinces blessed with energy resources, it is essential to utilize local energy resources and develop the energy resource industry to promote economic development. At the same time, the leading industry should still be attached with importance to prevent excessive dependence on energy resources.

For provinces with a level-one resource curse, this paper provided a policy prescription that the government should understand the economic impact of local energy resource industries and limit the use of local energy resources. There is a diversity of indirect transmission mechanisms and regional heterogeneity in the provinces. Hence, governments should fully investigate the impact of energy resource industries on the local economy, especially the roles of indirect transmission channels. Governments' goal should be reducing dependence on energy resources through transforming industrial structure. In this case, it is necessary to invest in human capital and develop high-grade industries to completely avoid the "invisible energy resource curse". Governments can also reform the property system and build a more competitive energy market.

This paper proposed specific measures to alleviate the resource curse for different mechanisms. First, optimizing the business environment to attract investment. Due to the state's absolute control over the mineral resources industry, the resource industry is prone to rent-seeking and corruption problems [1]. It results in a poor rule of law and government environment, which is not conducive to attracting capital inflows. Optimizing the business environment allows companies to devote more resources to productivity instead of rent-seeking activities that generate excess profits [81]. Such a legally regulated and transparent regulatory environment is conducive to attracting foreign investment, thereby offsetting the negative impact of resource dependence.

Second, attaching importance to the role of human capital. The crowding-out effect of resource dependence on talents requires us to increase education investment, attract and retain high-quality talents, and promote the accumulation of human capital.

Third, encouraging industrial upgrading and diversification. A good example is the creation of energy clusters based on mining companies. First of all, mining enterprise clusters can transform the comparative advantage based on resource endowment into a competitive advantage based on regional innovation capability. It greatly accelerates the technological innovation of enterprises in the cluster. This is because the cluster of mineral resource-based enterprises provides support for all stages of innovation of enterprises and makes the diffusion of technological innovation products more rapid [82-84]. Technological innovation increases the attraction to talents, and the inflow of talents further promotes technological innovation, thus alleviating the crowding-out effect of resource 
dependence on education and talents. Secondly, mining clusters promote the formation of a complete industrial chain, including upstream equipment manufacturing, downstream chemical, mineral processing, and other industries. It can reduce the crowding-out effect on manufacturing.

Finally, effective environmental regulation. An effective measure is the regulation of greenhouse gas emissions. Studies show that an industrial structure weighted towards heavy industry leads to China's large carbon emissions [85-87]. The transformation of industrial structure, especially the upgrading of the manufacturing industry, improves the efficiency of economic growth and reduces carbon emissions [88-90]. Therefore, the need to reduce greenhouse gas emissions will force the transformation and upgrading of the manufacturing structure, thus alleviating the Dutch disease. Table 9 shows that manufacturing is a major channel of the resource curse, so it can lower the level of the resource curse in most provinces.

Author Contributions: H.H.: Writing—original draft, Investigation, Funding acquisition and Supervision; W.R.: Formal analysis and Investigation; Y.W.: Writing — review \& editing; X.L.: Writing-original draft and Investigation. All authors have read and agreed to the published version of the manuscript.

Funding: This work was financially supported by the Major Program of National Social Science Foundation (No. 16ZDA006), National Natural Science Foundation of China (No. 71603193 and 71974151), and Fundamental Research Funds for the Central Universities in China (No. 105413000020).

Acknowledgments: The authors are grateful to the editor and anonymous reviewers for their insightful comments. We thank Tianyu Zheng for his great contributions to this paper.

Conflicts of Interest: The authors declare no conflict of interest.

\section{References}

1. Shao, S.; Yang, L. Natural resource dependency, human capital accumulation, and economic growth: A combined explanation for the resource curse and the resource blessing. Energy Policy 2014, 74, 632-642. [CrossRef]

2. Hajkowicz, S.A.; Heyenga, S.; Moffat, K. The relationship between mining and socio-economic wellbeing in Australia's regions. Resour. Policy 2011, 36, 30-38. [CrossRef]

3. James, A.; Aadland, D. The curse of natural resources: An empirical investigation of U.S. counties. Resour. Energy Econ. 2011, 33, 440-453. [CrossRef]

4. James, A.G.; James, R.G. Do resource dependent regions grow slower than they should? Econ. Lett. 2011, 111, 194-196. [CrossRef]

5. Frederick, V.D.P. Natural resources: Curse or blessing? J. Econ. Lit. 2011, 49, 366-420.

6. Papyrakis, E.; Raveh, O. An empirical analysis of a regional Dutch disease: The case of Canada. Environ. Resour. Econ. 2014, 58, 179-198. [CrossRef]

7. Cohen, P.J.; Lawless, S.; Dyer, M.; Morgan, M.; Saeni, E.; Teioli, H.; Kantor, P. Understanding adaptive capacity and capacity to innovate in social-ecological systems: Applying a gender lens. Ambio 2016, 45, 309-321. [CrossRef]

8. Konte, M. A curse or a blessing? Natural resources in a multiple growth regimes analysis. Appl. Econ. 2013, 45, 3760-3769. [CrossRef]

9. Chang, C.P.; Hao, Y. Environmental performance, corruption and economic growth: Global evidence using a new data set. Appl. Econ. 2017, 49, 498-514. [CrossRef]

10. Measham, T.G.; Walton, A.; Graham, P.; Fleming-Muñoz, D.A. Living with resource booms and busts: Employment scenarios and resilience to unconventional gas cyclical effects in Australia. Energy Res. Soc. Sci. 2019, 56, 101221. [CrossRef]

11. Liu, Y. Energy Production and Regional Economic Growth in China: A More Comprehensive Analysis Using a Panel Model. Energies 2013, 6, 1409-1420. [CrossRef]

12. Stevens, P.; Dietsche, E. Resource curse: An analysis of causes, experiences and possible ways forward. Energy Policy 2008, 36, 56-65. [CrossRef]

13. Fischer, A.P. Pathways of adaptation to external stressors in coastal natural-resource-dependent communities: Implications for climate change. World Dev. 2018, 108, 235-248. [CrossRef]

14. Arezki, R.; Sy, A.; Gylfason, T. Beyond the curse: Policies to harness the power of natural resources. Afr. Growth Agenda 2015, 10, 12-14. 
15. Satti, S.L.; Farooq, A.; Loganathan, N.; Shahbaz, M. Empirical evidence on the resource curse hypothesis in oil abundant economy. Econ. Model. 2014, 42, 421-429. [CrossRef]

16. Papyrakis, E. A development curse: Formal vs informal activities in resource-dependent economies. Int. J. Soc. Econ. 2014, 41, 244-264. [CrossRef]

17. Yuxiang, K.; Chen, Z. Resource abundance and financial development: Evidence from China. Resour. Policy 2011, 36, 72-79. [CrossRef]

18. Doraisami, A. Has Malaysia really escaped the resources curse? A closer look at the political economy of oil revenue management and expenditures. Resour. Policy 2015, 45, 98-108. [CrossRef]

19. Sachs, J.; Warner, A. Natural Resource Abundance and Economic Growth; NBER Working Paper No. 5398; National Bureau of Economic Research: Cambridge, MA, USA, 1995.

20. Sachs, J.D.; Warner, A.M. The curse of natural resources. Eur. Econ. Rev. 2001, 45, 827-838. [CrossRef]

21. Papyrakis, E.; Gerlagh, R. Resource abundance and economic growth in the United States. Eur. Econ. Rev. 2007, 51, 1011-1039. [CrossRef]

22. Havranek, T.; Horvath, R.; Zeynalov, A. Natural Resources and Economic Growth: A Meta-Analysis. World Dev. 2016, 88, 134-151. [CrossRef]

23. Fleming-Muñoz, D.A.; Measham, T.G.; Paredes, D. Understanding the resource curse (or blessing) across national and regional scales: Theory, empirical challenges and an application. Aust. J. Agric. Resour. Econ. 2015, 59, 624-639. [CrossRef]

24. Huang, L.; Wu, J.; Yan, L. Defining and measuring urban sustainability: A review of indicators. Landsc. Ecol. 2015, 30, 1175-1193. [CrossRef]

25. Kim, M.J.; Park, S.Y.; Sang, Y.J. An empirical test for Okun's law using a smooth time-varying parameter approach: Evidence from East Asian countries. Appl. Econ. Lett. 2015, 22, 788-795. [CrossRef]

26. Blanco, L.; Grier, R. Natural resource dependence and the accumulation of physical and human capital in Latin America. Resour. Policy 2012, 37, 281-295. [CrossRef]

27. Oskenbayev, Y.; Yilmaz, M.; Abdulla, K. Resource concentration, institutional quality and the natural resource curse. Econ. Syst. 2013, 37, 254-270. [CrossRef]

28. Idemudia, U. The resource curse and the decentralization of oil revenue: The case of Nigeria. J. Clean. Prod. 2012, 35, 183-193. [CrossRef]

29. Hammond, J.L. The resource curse and oil revenues in Angola and Venezuela. Sci. Soc. 2011, 75, 348-378. [CrossRef]

30. Auty, R.M. Sustaining Development in Resource Economies: The Resource Curse Thesis; Routledge: London, UK; New York, NY, USA, 1993.

31. Xu, X.; Xu, X.; Chen, Q.; Che, Y. The research on generalized regional "resource curse" in China's new normal stage. Resour. Policy 2016, 49, 12-19. [CrossRef]

32. Shao, S.; Qi, Z. Energy exploitation and economic growth in western China: An empirical analysis based on the resource curse hypothesis. Front. Econ. China 2009, 4, 125-152. [CrossRef]

33. Xu, Y.; Hu, Y. The relationship between economic development mode and natural resource advantages in Inner Mongolia: An empirical analysis based on the resource curse hypothesis. Resour. Sci. 2010, 32, 2391-2399.

34. Sun, Y.; Ye, C. Resource dependency, locations and city economic growth. Mod. Econ. Sci. 2011, 33, 114-123. (In Chinese)

35. Shao, S.; Fan, M.; Yang, L. How does resource-dependent industry effect economic development efficiency: Test and interpretation of conditional resource curse hypothesis. Manag. World 2013, 2, 32-63. (In Chinese)

36. Ding, C.; Ma, P.; Liao, S. Resource curse and measurement of its micro mechanism. China Popul. Resour. Environ. 2018, 28, 138-147.

37. Fang, Y.; Ji, K.; Zhao, Y. Whether there is a source curse in China? J. World Econ. 2011, 4, 144-160. (In Chinese)

38. Deng, T.; Ma, M.; Cao, J. Tourism resource development and long-term economic growth: A resource curse hypothesis approach. Tour. Econ. 2014, 20, 923-938. [CrossRef]

39. Sun, D.; Si, M. On resource abundance and China's regional economic growth: A query on resource curse hypothesis. J. Zhongnan Univ. Econ. Law 2012, 1, 84-89.

40. Cao, S.; Hu, D.; Zhao, W.; Mo, Y.; Chen, S. Monitoring Spatial Patterns and Changes of Ecology, Production, and Living Land in Chinese Urban Agglomerations: 35 Years after Reform and Opening Up, Where, How and Why? Sustainability 2017, 9, 766. [CrossRef] 
41. Wang, Z.; Zhang, F.; Wu, F. Intergroup neighboring in urban China: Implications for the social integration of migrants. Urban Stud. 2016, 53, 651-668. [CrossRef]

42. Chen, T.; Kung, J.S. Do land revenue windfalls create a political resource curse? Evidence from China. J. Dev. Econ. 2016, 123, 86-106. [CrossRef]

43. Guo, J.; Zheng, X.; Song, F. The Resource Curse and Its Transmission Channels: An Empirical Investigation of Chinese Cities' Panel Data. Emerg. Mark. Financ. Trade 2016, 52, 1325-1334. [CrossRef]

44. $\mathrm{Li}, \mathrm{T}$. Research on the Influence of Natural Resource Abundance on China's Regional Economic Growth and Its Transmission Mechanism. Econ. Sci. 2007, 6, 66-76. (In Chinese)

45. Wang, Z. Empirical study on resource curse transmission mechanism of resource-based cities. Urban Stud. 2011, 11, 85-89.

46. Yang, L.; Shao, S. Human capital migration and resource curse effect: How to achieve the sustainable growth of resource-oriented regions. J. Financ. Econ. 2014, 11, 44-60.

47. Zuo, N.; Schieffer, J. Are Resources a Curse? An Investigation of Chinese Provinces; Southern Agricultural Economics Association (SAEA): Dallas, TX, USA, 2014.

48. He, Q. Quality-Adjusted Agricultural Land Abundance Curse in Economic Development: Evidence from Post-reform Chinese Panel Data. Emerg. Mark. Financ. Trade 2015, 51, S23-S39. [CrossRef]

49. Uçak, H. The catch-up process of relative wages in European Union new member states. Ekon. Cas. 2012, 4, 360-370.

50. Jalloh, M. Regional economic integration and incomes convergence: A case study of the economic community of West African states. J. Econ. Sustain. Dev. 2014, 5, 81-93.

51. Berry, H.; Guillén, M.F.; Hendi, A.S. Is there convergence across countries? A spatial approach. J. Int. Bus. Stud. 2014, 45, 387-404. [CrossRef]

52. Borsi, M.T.; Metiu, N. The evolution of economic convergence in the European Union. Empir. Econ. 2015, 48, 657-681. [CrossRef]

53. Dong, B.; Zhang, Y.; Song, H. Corruption as a natural resource curse: Evidence from the Chinese coal mining. China Econ. Rev. 2019, 57, 101314. [CrossRef]

54. Song, M.; Wang, J.; Zhao, J. Coal endowment, resource curse, and high coal-consuming industries location: Analysis based on large-scale data. Resour. Conserv. Recycl. 2018, 129, 333-344. [CrossRef]

55. Liang, Y.; Zheng, Y.Q. The relationship between natural resources and economic growth: An inverted U curve hypothesis. Res. Financ. Econ. Issues 2015, 10, 9-14.

56. Dreger, C.; Zhang, Y. On the relevance of exports for regional output growth in China. Appl. Econ. 2014, 46, 4302-4308. [CrossRef]

57. Schuele, S.A.; Hilz, L.K.; Dreger, S.; Bolte, G. Social inequalities in environmental resources of green and blue spaces: A review of evidence in the WHO European Region. Int. J. Environ. Res. Public Health 2019, 16, 1216. [CrossRef] [PubMed]

58. Fan, R.; Fang, Y.; Park, S.Y. Resource abundance and economic growth in China. China Econ. Rev. 2012, 23, 704-719. [CrossRef]

59. Davis, G.A. The resource drag. Int. Econ. Econ. Policy 2011, 8, 155-176. [CrossRef]

60. Frederick, V.D.P.; Poelhekke, S. The pungent smell of 'red herrings': Subsoil assets, rents, volatility, and the resource curse. J. Environ. Econ. Manag. 2010, 60, 44-55.

61. Wang, Q.; Su, M.; Li, R.; Ponce, P. The effects of energy prices, urbanization and economic growth on energy consumption per capita in 186 countries. J. Clean. Prod. 2019, 225, 1017-1032. [CrossRef]

62. Arezki, R.; Lederman, D.; Zhao, H. The relative volatility of commodity prices: A reappraisal. Am. J. Agric. Econ. 2014, 96, 939-951. [CrossRef]

63. Rahmati, M.H.; Karimirad, A. Subsidy and natural resource curse: Evidence from plant level observations in Iran. Resour. Policy 2017, 52, 90-99. [CrossRef]

64. Hu, H.; Jin, Q.; Kavan, P. A study of heavy metal pollution in China: Current status, pollution-control policies and countermeasures. Sustainability 2014, 6, 5820-5838. [CrossRef]

65. Stijns, J.P.C. Natural resource abundance and economic growth revisited. Resour. Policy 2005, 30, 107-130. [CrossRef]

66. Gylfason, T.; Zoega, G. Natural resources and economic growth: The role of investment. World Econ. 2006, 29, 1091-1115. [CrossRef] 
67. Papyrakis, E.; Gerlagh, R. The resource curse hypothesis and its transmission channels. J. Comp. Econ. 2004, 32, 181-193. [CrossRef]

68. Hoenderdaal, S.; Espinoza, L.T.; Marscheider-Weidenmann, F.; Graus, W. Can a dysprosium shortage threaten green energy technologies? Energy 2013, 49, 344-355. [CrossRef]

69. Wang, Z.; Lu, H.; Han, Z. An analysis of the spatial and temporal differentiation and driving factors of the marine resource curse in China. Ocean Coast. Manag. 2018, 155, 60-67. [CrossRef]

70. Zhong, T.; Zhang, X.; Huang, X.; Liu, F. Blessing or curse? Impact of land finance on rural public infrastructure development. Land Use Policy 2019, 85, 130-141. [CrossRef]

71. Khan, M.A.; Khan, M.Z.; Zaman, K.; Arif, M. Global estimates of energy-growth nexus: Application of seemingly unrelated regressions. Renew. Sustain. Energy Rev. 2014, 29, 63-71. [CrossRef]

72. Zellner, A. An efficient method of estimating seemingly unrelated regressions and tests for aggregation bias. Publ. Am. Stat. Assoc. 1962, 57, 348-368. [CrossRef]

73. Huang, Y.; Fang, Y.; Zhang, Y.; Liu, J. A study of resource curse effect of Chinese provinces based on human developing index. Chin. Geogr. Sci. 2014, 24, 732-739. [CrossRef]

74. Hu, H.; Xie, N.; Fang, D.; Zhang, X. The role of renewable energy consumption and commercial services trade in carbon dioxide reduction: Evidence from 25 developing countries. Appl. Energy 2018, 211, 1229-1244. [CrossRef]

75. Huang, Y.; Todd, D.; Zhang, L. Capitalizing on energy supply: Western China's opportunity for development. Resour. Policy 2011, 36, 227-237. [CrossRef]

76. Tang, L.; Ma, X.; Zhou, Y.; Shi, X.; Ma, J. Social relations, public interventions and land rent deviation: Evidence from Jiangsu Province in China. Land Use Policy 2019, 86, 406-420. [CrossRef]

77. Ogwang, T.; Vanclay, F.; van den Assem, A. Rent-Seeking Practices, Local Resource Curse, and Social Conflict in Uganda's Emerging Oil Economy. Land 2019, 8, 53. [CrossRef]

78. Hoechle, D. Robust standard errors for panel regressions with cross-sectional dependence. Stata J. 2007, 7, 281-312. [CrossRef]

79. Chai, S.; Zhang, Z.; Ge, J. Evolution of environmental policy for China's rare earths: Comparing central and local government policies. Resour. Policy 2020, 68, 101786. [CrossRef]

80. Zhang, Q.; Li, H.; Zhu, L.; Campana, P.E.; Lu, H.; Wallin, F.; Sun, Q. Factors influencing the economics of public charging infrastructures for EV-A review. Renew. Sustain. Energy Rev. 2018, 94, 500-509. [CrossRef]

81. Sobel, R.S. Testing Baumol: Institutional quality and the productivity of entrepreneurship. J. Bus. Ventur. 2008, 23, 641-655. [CrossRef]

82. Wang, F.; Guo, X. The Path of Transformation and Upgrading on Mineral Resource-based Enterprises Based on Sustainability Science: Derived from Empirical Data of Inner Mongolia. J. Ind. Technol. Econ. 2012, 10, 64-72.

83. Bithas, K.; Kalimeris, P. Revisiting the Energy-Development Link: Evidence from the 20th Century for Knowledge-Based and Developing Economies; Springer: Heidelberg/Berlin, Germany, 2015.

84. Zhou, X.; Zhang, J.; Li, J. Industrial structural transformation and carbon dioxide emissions in China. Energy Policy 2013, 57, 43-51. [CrossRef]

85. Gruber, J. Revising the Resource Curse Using a Physical Resource Abundance Indicator. Ph.D. Thesis, University of Vienna, Wien, Austria, 2014.

86. Gylfason, T.; Zoega, G. The Dutch Disease in Reverse: Iceland's Natural Experiment; Research Paper No. 138; Oxford Centre for the Analysis of Resource Rich Economies, University of Oxford: Oxford, UK, 2014.

87. James, A. The resource curse: A statistical mirage? J. Dev. Econ. 2015, 114, 55-63. [CrossRef]

88. Leong, W.; Kamiar, M. Institutions and the Volatility Curse; Working Paper: SSRN 1885569; University of Cambridge: Cambridge, UK, 2011.

89. Li, H.; Long, R.; Chen, H. Economic transition policies in Chinese resource-based cities: An overview of government efforts. Energy Policy 2013, 55, 251-260. [CrossRef]

90. Liu, Q.; Reilly, B. Income transfers of Chinese rural migrants: Some empirical evidence from Jinan. Appl. Econ. 2004, 36, 1295-1313. [CrossRef]

(C) 2020 by the authors. Licensee MDPI, Basel, Switzerland. This article is an open access article distributed under the terms and conditions of the Creative Commons Attribution (CC BY) license (http://creativecommons.org/licenses/by/4.0/). 